\title{
Eco-bioengineering Tools in Ecohydrological Assessment of Eutrophic Water Bodies
}

\author{
Nayanmoni Gogoi ( $\nabla$ nayanmoni@tezu.ernet.in ) \\ Tezpur University \\ Bishal Paul \\ Tezpur University \\ Karishma Das Purkayastha \\ Tezpur University
}

\section{Research Article}

Keywords: Restoration, eutrophication, biomanipulation, ecohydrology, eco-engineering

Posted Date: February 16th, 2021

DOI: https://doi.org/10.21203/rs.3.rs-193922/v1

License: (c) (i) This work is licensed under a Creative Commons Attribution 4.0 International License. Read Full License 


\section{Abstract}

Eutrophication of water bodies and deterioration of water quality is an emerging environmental crisis. The root causes, pathways and consequences of eutrophication are multidirectional and provide a huge scope of riskanalysis and risk-assessment in the domain of remediation studies. However, a deep insight on restoration studies shows a global transitional trend of evolution of traditional restoration methods to advanced innovative techniques with pioneering development in the field of science and technology. This study introduces a novel approach of considering ecohydrological assessment of eutrophication emphasizing classical biomanipulation practices and their evolution into innovative methods coined as 'eco-bioengineering' method. The main objective of this study is to critically analyse and recognize the research gaps in classical biomanipulations and appreciate the reproducibility and efficacy of eco-bioengineering methods at micro- and macrolevel aquatic ecosystems. Comprehensive literature review was conducted in offline and online planforms, and our survey revealed continuation of a historical trend in classical biomanipulation practices (75.36\%) and an ascending drift in eco-bioengineering research (24.64\%) in the immediate decade (2010-2020). At a global scale, recent biomanipulation research is skewedly distributed in Europe (43.48\%), East Asia (34.78\%), North America (8.70\%), South America (2.90\%), South Africa (4.35\%), Oceania (1.45\%), Middle East (1.45\%) and non-specific regions (2.90\%). Finally, this study revealed the comprehensiveness of eco-bioengineering methods and their strong ecological resilience to recurrence of eutrophication and fluctuating environmental flows in the future. Therefore, this study reinforces eco-bioengineering methods a cost-effective green technologies that will sustainable solutions for restoration of eutrophic waters at a global scale.

\section{Introduction}

Eutrophication is characterized by change in water quality, loss of aquatic habitat, proliferation of algal blooms and rapid growth of macrophytes. Eutrophication affects nutrient dynamics, environmental flows and ecological niches of aquatic systems (Carey et.al. 2009). Municipal sewage and agricultural runoff are emerging as trouble for freshwater bodies as they cause exogenous enrichment with inorganic and organic contaminants (Kumwimba and Meng 2019; Zhang et al. 2014). Uncontrolled flow of sewage and effluents steer eutrophication of waters causing serious ecohydrological imbalances (Paul et al. 2020; Sharpley 2008). One of the alarming consequences of eutrophication is proliferation of harmful algal blooms (HABs), which greatly perturb aquatic ecosystems in several ways (Smith 2009). HABs are visual indicators of eutrophication and are mostly cyanobacterial blooms (Aphanizomenon, Cylindrospermopsis, Dolichospermum, Microcystis, Nodularia, Planktothrixand Trichodesmium etc.) (Wiegand 2005; Berdalet 2016; Huisman 2018) HABs deplete oxygen levels in natural water systems, produces cyanotoxins, and hinders penetration of light into the euphotic zone affecting the population of submerged flora and fauna (Anderson 2009). In addition, cyanobacterial blooms can create a number of cyanotoxins when eaten by birds, mammals, and humans leading to acute (liver, digestive, and neurological) disorder (Carmichael et al. 2001; Metcalf et al. 2012; Merel et al. 2013). Literature shows that eutrophication has become a common phenomenon and geographic distribution of HABs is uniformly rising year after year (Paul et al. 2020). Despite the fact that upstream flow management may lessen the quantity and toxicity of sewage and effluents, it is not fully possible to prevent entry of pollutants into water bodies (Wu 2017). In the new era of scientific development and technological upgradation of existing water treatment methods, ecohydrology has been observed as an interdisciplinary approach to address all hydrochemical and geochemical aspects of water bodies. This review highlights the role of ecohydrological approaches in treating eutrophication, highly emphasizing on classical biomanipulation methods and advanced ecological and bioengineering methods of restoring eutrophic waters. 
Eutrophication management practices involve a variety of physical, chemical, and biological methods for treatment of eutrophic water bodies by giving top-notch approaches for reduction, recuperation, and reuse of nutrients and contaminants (Newman et al. 2006; Pärn et al. 2020). For over a century, conventional methods have been successfully applied in treating wastewaters including eutrophic waters. However, with the advancement of information, knowledge and technology, newer and innovative techniques have either replaced or modified the conventional methods for better treatment of eutrophic water bodies (Zhang et al. 2020). Biomanipulation is one such effective ecohydrological tool that modifies the aquatic biodiversity to restore eutrophic waters. In course of time, biomanipulation has become a very promising ecohydrological tool and evolved as eco-bioengineering method of treatment of eutrophication (Paul et al. 2020; Zhang et al. 2020). The current review introduces a novel approach of identifying the research gaps in classical biomanipulation practices and proposes an interdisciplinary scope of overcoming this discontinuity by prioritizing ecohydrological and eco-bioengineering methods. The main goal of this study is to address the evolutionary pathways of classical biomanipulation practices to innovative ecobioengineering methods and endorse it as one of the best suitable ecohydrological approach for treatment of eutrophication. Therefore, this study includes the following specific objectives -

- Propagation of ecohydrological management and evolution of conventional biological restoration methods

- Comprehensive study on biomanipulation of eutrophic water bodies

- Reinforcement of biomanipulation as an eco-bioengineering tool for treatment of eutrophic water bodies.

Our study focusses primarily on endorsement of biomanipulation as an innovative eco-bioengineering method of rehabilitation of eutrophic water bodies. Electronic mode of literature review revealed that biomanipulation is the most primitive form of ecological engineering tool that evolved over time as eco-friendly bioengineering method (Mannina et al. 2020). Biomanipulation has been recognized as an eco-bioengineering tool since early 1990 s and reported as an excellent technique to expedite the process of rehabilitation without causing any ecological imbalance in eutrophic water bodies.

\section{Methodological Approach}

The main objective of the study is to critically analyse classical biomanipulation methods and identify the progressive transition pathways into sustainable eco-bioengineering methods of restoring eutrophic water bodies. Methodology of study included offline and online or electronic mode of literature review to obtain relevant information from original research articles, e-reports, archives and reports published by government agencies, detailed in Fig. 1. Offline literature survey was conducted by collecting information from books, magazines and scholarly journals in libraries. Online study was conducted by browsing and downloading articles from bibliographic databases like Scopus, Web of Science, ScienceDirect, Google Scholar, PubMed and Research Gate following Paul et al (2020) and Das et a (2019). Keywords as 'ecohydrology', 'classical', 'historical' 'biomanipulation', 'eutrophication', 'ecological', 'engineering' and 'bioengineering' were used to find relevant information based on the objectives of the study. Our literature survey revealed that biomanipulation is the earliest ecological engineering tool, practiced since early 1990 s and progressively evolved over decades as eco-bioengineering methods. It was also discovered that classical biomanipulation practices reformed as eco-bioengineering methods within a time span of only three decades. The retrieved information was strategically arranged into various sections and sub-sections to obtain a meaningful gist of the entire study. However, final drafting of the retrieved information on biomanipulation research was partially justified due to various constraints in offline and online accessibility and privacy policies at spatial and temporal scales.

Page $3 / 30$ 


\section{Propagation Of Ecohydrological Management And Evolution Of Conventional Biological Restoration Methods}

Eutrophication occurs naturally when water bodies age and gets inundated with sediment over a long period of time (Carpenter 1981). However, the rate and extent of eutrophication is aggravated by anthropogenic introduction of point source and non-point source pollutants into aquatic ecosystems, causing depletion of multipurpose water resources, fish breeding, and aesthetical activities (Carpenter et al. 1998). In early 1960s, investigators linked the root causes of algal blooms and nutrient enrichment to major land use activities like agriculture, industrial establishments, and urbanization (Schindler 1974). Eutrophication exacerbates deterioration of water quality by promoting noxious and foul smelling HABs. Dense algal blooms reduce light penetration in littoral zones and affect predators requiring luminescence for on physiological activities (Lehtiniemi et al. 2005). Algal blooms eventually die and create a hypoxic environment also known as 'dead zone'. 'Dead zones' are reported during the summer in the Laurentian Great Lakes e.g., central basin of Lake Erie (Arend et al. 2011). Hypoxia and gradually anoxia results from extreme eutrophication cases termed as hyper-eutrophication (Sebastiá-Frasquet et al. 2020). The effects and causes of eutrophication are represented in Fig. 2. These ecological problems may be collectively addressed by ecohydrological interventions and can be resolved through interdisciplinary approaches to rejuvenate the water bodies facing recurring eutrophication hazards (Paul et al. 2020).

Ecohydrology is an interdisciplinary science that deals with aquatic ecological systems upholding the basic principles of physical, chemical, biological and engineering sciences. Ecohydrology encompasses an array of methods functioning through various modes of operation as hydrophysical, hydrochemical, hydrobiological and innovative bio-ecoengineering methods (Paul et al. 2020). Ecohydrological history dates back to early 90 s, Zalewski et al (1997) led a pioneering study on short-term and long-term hydrodynamic process in relation to ecological systems. For the first time, the International Hydrology and Man and Biosphere programs under UNESCO, familiarized the concept of ecohydrology at a global platform and motivated researchers to address it in ecosystem functions of freshwater bodies (Zalewski et al. 1997). Later, the idea of ecohydrological approach in managing freshwater ecosystems have been recognized and gradually applied in studying interactions between biotic processes and the hydrological cycle (Nuttle 2002). In modern times, innovative eco-engineering methods of water treatment are observed as new developments under the umbrella of ecohydrology. Ecohydrology provides a sustainable approach to restore eutrophic water bodies including top-down and bottom-up methods in ecosystem management, and it has been successfully implemented in many polluted coastal estuaries (Wolanski et al. 2015). Ecohydrology is a multidisciplinary approach reinstating the conventional methods of water treatment in a productive way (Paul et al. 2020). Ecohydrological treatments are conducted as ex-situ or in-situ processes depending on the requirement, nature, and level of eutrophication. In-situ ecohydrological interventions are considered beneficial over ex-situ methods as it decreases the expense of transportation from the original site of treatment and hence overcomes the risk of externalities (Paul et al. 2020).

\section{Biomanipulation In Eutrophic Water Bodies}

Biomanipulation is a trending area of ecohydrological research, and over the past 30 years it has been appraised for restoring eutrophic water bodies (Mehner et al. 2002; Arlinghaus et al. 2015). It involves in-situ exploration of ecohydrological tools in managing ecologically unstable food-web in stressed water bodies. Technically, biomanipulation may be defined as a series of manipulations events that modify biotic components or their ecological niches to improve water quality and reduce eutrophication (Shapiro 1990; Shapiro et al.1975). These events target ecological food-chains by adding or removing some important organisms or key species from aquatic

Page $4 / 30$ 
systems. Usually, biomanipulation involves addition or removal of benthivorous, zoo-planktivorous, and piscivorous fishes to manage populations of grazing zooplankton, especially Daphnia sp. (Jeppesen et al. 2012). For example, Daphnia sp. actively graze on phytoplankton especially harmful algal blooms (HABs) in eutrophic water bodies and improve clarity and quality of water (Dionisio Pires 2005). However, the grazing activity of zooplankton is affected by excessive predation (by macroinvertebrates and fishes), insufficient feed stock, and harmful algal toxins (Benndorf et al. 2000). Biomanipulation experiments can be performed in in-vitro conditions to obtain an optimized species composition and extended to field conditions for sustainable and long-term effective results (Fig. 3).

In the late 20th century, a new concept of trophic cascade hypothesis revolutionized the biomanipulation techniques (Shapiro and Wright 1984). Trophic cascade involves "top-down" and "bottom-up" approaches in biomanipulation techniques. Removal of planktivorous fish and increases population of large-sized Daphnia which feeds on the phytoplankton and gradually decreases cyanobacterial blooms (Lammens 1999; Drenner and Hambright 1999). The hypothesis of trophic cascade is based on "top-down" biomanipulation confirmed by lab-scale investigations, in secluded artificial aquatic ecosystems (Christoffersen et al. 1993). Trophic cascade is also supplemented by transplantation of submerged macrophytes that prevents resuspension of sediment, this practice is most suitable for restoration of warm shallow lakes (Christoffersen et al. 1993). Trophic cascade hypothesis thus revolves around removal of species from an aquatic system depending on the species composition and stress level of a water body.

\subsection{Evolution of biomanipulation}

Biomanipulation can be performed in a number of ways by choosing a key species in any aquatic system. In classical biomanipulation methods, the key species is usually a fish, however, biomanipulation has evolved over years and researchers are nowadays using newer techniques in maintaining a healthy species ratio in aquatic ecosystems. Mehner et al (2002) showed that successful biomanipulation depends on the food-web structure that affect food-web complexity and success rate of various biomanipulation studies and revealed a few important observations - (1) contribution of aquatic organisms in nutrient recycling 2) role of morphology and physiology of aquatic organisms in food-web interactions and (3) requirement of an equilibrium between aquatic communities like piscivores, planktivoress, and benthivores. Dense fish populations rigorously prey upon zooplankton (cladocerans, copepods and rotifers), reduces algal blooms and increases transparency of water (Andersson et al.. 1978). Some of the frequently practiced classical biomanipulation techniques are discussed below:

\subsubsection{Biomanipulation involving planktivores and piscivores}

It is evident that proper management of piscivores, zooplanktivores/benthivores and zooplankton in experimental enclosures may help in obtaining a balanced species composition (Jacobsen et al. 1997). Gladyshev et al (2003) reported that a reduction in number of planktivorous fish, Carassius auratus significantly lowered cyanobacterial blooms in a small reservoir in Bugach River, Russia. Planktivorous fishes as crucian carps ingest cyanobacteria while filtering their primary food i.e., zooplankton (Kolmakov and Gladyshev 2003). A study showed that bighead carp and silver carp (at a density of $65-75 \mathrm{~g} / \mathrm{m}^{3}$ ) inputs caused a sharp decline in the biomass of total phytoplankton in just 14 days accompanied by disappearance of algal blooms from the culturing enclosures (Ping 1996). However, grass carp is not much effective in reducing phytoplankton biomass or controlling water bloom and grazing zoo-plantivores (Ping 1996). The outcome of this study revealed that phytoplankton community was dominated by large sized species $(>30 \mu \mathrm{m})$ in both fish-free and grass carp stocked enclosures. Ping (1996) reported that in waters stocked with a high density planktivorus fishes (i.e., silver carp and bighead carp), small sized (<30 $\mu \mathrm{m})$ phytoplankton community dominated. Another study showed that in culture enclosure stocked with silver carp 
and bighead carp fishes at various weight ratios (1:0, 1:1, and 1:2) as well as a control group with no fish led to significant decrease in chlorophyll-a and total phosphorus levels were (Yi 2016). Grass carp (Ctenopharyngodon idella) is a voracious macrophyte feeder, reduces a submerged macrophytes and increases nutrient concentrations. Similar studies shows that planktivorous fishes and rotifers, cladocerans, and overall zooplankton population decreases after macrophyte removal (Maceina1992). Therefore, addition of zoo-planktivorous fishes may have a deleterious impact on zooplankton community.

Experimental models illustrate the pathways of planktivorous fish affecting viability of blue green algae while passing through fish intestine (McQueen 1990). It has been reported that both colonial and filamentous forms of blue green algae can withstand digestion process in planktivorous fish gut and eventually increase their primary productivity (Miura and Wang 1985). Reduction in the number of zoo-planktivores in a lake may increase the size and grazing activities of herbivorous zooplankton accompanied by significant reduction in cyanobacterial abundance and a shift from small-bodied to large-bodied Daphnia sp. Gradual shift from Daphnia ambigua to Daphnia parvula and Daphnia parvula to Daphnia galeata and finally Daphnia pulex is a common outcome observed in biomanipulation experiments. Post-biomanipulation effects appear as fallen concentrations of TP and TN, epilimnion chlorophyll, dominant population of larger, and increased transparency of water. This substantially increases the grazing pressure of newly dominant zooplankton communities, survival rate in even low concentrations of chlorophyll and few algal communities, and presence of high inorganic $\mathrm{N}$ and $\mathrm{P}$ concentrations (Will and Wright 1984).

Shallow eutrophic lakes are often treated with rotenone to curb the populations of planktivorous fish e.g., Coregonus lavaretus (Sanni \& Wærvågen 1990). This elimination leads to dominance of rotifers and decrease in chlorophyll-a, nutrients, and algal blooms, while increase in poulations of Daphnia galeata and transparency of water (Sanni \& Wærvågen 1990). These activities further create an anomaly in the ecological food chain and aquatic species composition by mainly affecting the zooplankton community thereby leads to an oligotrophic condition. Decrease in chlorophyll-a to $\mathrm{P}$ ratio also indicates inconsistent nutrient cycling and increased predation on herbivorous zooplankton that shifts a lake to oligotrophic state (Karjalainen et al. 1999). Additionally, imbibing piscivores and reducing zoo-planktivores can create an upsurge in zooplankton biomass, and transitions between cladoceran and copepod or rotifer assemblages, following reduction in phytoplankton biomass, and loss of photosynthetic activity (Carpenter et al. 1987). Another experiment conducted in eutrophic Væng Lake, Denmark showed that removal of 2.5 tons of bream (Abramisbrama) and roach (Rutilus rutilus) during spring season caused $50 \%$ reduction in the total planktivorous/benthivorous fish biomass. This created a remarkable shift in the dominance of zooplankton community, succeeded by rotifers and larger cladocerans (Sondcrgaard et al. 1990). In Bautzen Reservoir (Dresden County), introduction of predators like Salmo gadrdneri in a predator-free system, greatly reduced the biomass of zoo-planktivores, specifically Leucaspiusde lineates (Benndorf et al. 1984). In absence of predatory fishes, biomass of zooplankton may increase up to $400 \%$ and phytoplankton species may reduce significantly (Benndorf et al. 1984). A Secchi disc may be used to determine the zone of light penetration in eutrophic wetlands, depth, it is an efficient mechanism to identify a change in phytoplankton composition relating to the depth of euphotic zone in a lake (Benndorf et al. 1984). One sign of successful biomanipulation is restoration of ecological niches, equally effective for zoo-planktivores, zooplankton, phytoplankton and macrophytes (Bund et al. 2002).

\subsubsection{Biomanipulation involving submerged macrophytes}

Submerged plants prepare a platform for stocking piscivores that can control populations of rigorous predator fishes and sedimentation activities without affecting the natural ecological balance (Drenner \& Hambright 1999). In presence of submerged macrophytes, benthivorous fish removal can control sedimentation, because high 
populations of zooplankton will rapidly graze on phytoplankton, thereby minimize oxygen consumption, and oxidation of sediment preventing P-release. Therefore, biomanipulation may be enhanced by introduction of adequate species of submerged plants to restore eutrophic shallow lakes (Carignan \& Kalff 1980; Jaynes \& Carpenter 1986). Submerged plants improve clarity of water and promotes growth of useful benthic algae by directly up taking nutrients and pollutants, limiting phosphorus $(P)$ release from sediment by oxidation of sediment and increasing the P-binding capacity of sediments and preventing sedimentation of particles in the water column that affects light assimilation by phytoplankton (Carignan \& Kalff 1980; Blindow et al. 1993; Barko \& James 1998; Zhang $X$ et al. 2017). This combined biomanipulation and submerged species treatment also promotes dominance of large-bodied Daphnia magna), showing high densities during spring and summer.

Involvement of submerged macrophyted in biomanipulation experiments showed a positive effect on restoration of water quality and maintaining a healthy ecosystem, especially in temperate lakes in European countries. (Jeppesen et al. 2012). In warm lakes, re-introduction of submerged vegetation had negligible effect on fish and zooplankton abundance. Introduction of macrophyte beds offer shelter and protection of zooplankton from planktivorous fish (Timms and Moss 1984). Macrophyte beds also provide a platform multiplication and feeding ground for the zooplankton (Barko and James 1998). However, assemblage of zooplankton at the vicinity of macrophytes becomes scanty in presence of omnivorous fish predators (dominant), and hence predation of zooplankton near the dense vegetation in warm shallow lakes (Meerhoff 2003; Jeppesen 2007; Liu 2014). Therefore, fish abundance, especially omnivores is apparent in warm shallow lakes in sub-tropical regions than the temperate regions (Zhao et al. 2006; Teixeira-de Mello et al. 2009). Young omnivorous fishes are dominant in warm lakes that rapidly feed on zooplankton, whereas the adult fishes consume the abundant macrophytes (González-Bergonzoni 2012). But submerged macrophytes may sometimes release chemicals mostly allelopathic substances that may have adverse impacts on the aquatic communities, however, there is minimal information on the mode and mechanism of action of these allelopathic substances (Donk \& Bund 2002). Eichhornia crassipes, Pistia stratiotes, Salvinia molesta, Hydrilla verticillate, Myriophyllum aquaticum, Elodea nuttallii etc. are some of the macrophytes reported in effective biomanipulation techniques.

\subsubsection{Biomanipulation involving zooplankton}

Zooplankton is another key species in biomanipulation experiments, removal or addition of zooplankton affects the feeding activities of zoo-planktivores. Zooplankton grazing activity facilitates to a clear-water period, in most of the mesotrophic and eutrophic lakes, and measured by Secchi disc transparency i.e., drop in chlorophyll concentration (Lampert 1986). In other words, the rate of zooplankton grazing is directly proportional to clarity of water. It has been reported that before attainment of a clear water phase, small phytoplankton communities $(<35 \mu m$ size $)$ contribute to around $88 \%$ of the primary productivity presence of zooplankton stimulates the growth of large size planktons (Lampert et al. 1986). In presence of actively feeding adult copepod species as Pseudocalanus, Temoralongicornis, Oithonasimilis, and Acartiatonsa (1-15 $\mu$ ) in Bras d'Or Lake and Morrison's Pond, Cape Breton Island, a skewed daily zooplankton food intake and non-uniform primary production was observed at the depths of maximum photosynthesis (Hargrave and Geen 1970). Abiotic variables like reduced pH, water transparency and total phosphorus levels are linked to primary productivity of the phytoplankton communities (Schoenberg et al. 1984). Daphnia is another species that rapidly feed on cyanobacteria (Microcystis), Daphnia longispina can reduce population of Anabaena flos-aquae (cyanobacteria) by a factor of 350, resulting increase in transparency of water in mid-summer (Ger 2016). D. longispina can also reduce the population of Microcystis aeruginosa, and effectively restore eutrophic water bodies (Pogozhev et al. 2001). However, cladocerans, copepods, and rotifers have differential feeding abilities. Copepods use chemical signals to choose algal feed of a particular size range. As a 
result, Copepods are selective slow feeders as compared to cladocerans and rotifers (Bogdan and McNaught 1975). Rotifers prey on small algal cells, for example, Brachionus calyciflorus cleared smaller Microcystis $(<20 \mu \mathrm{m}$ diameter) at a rate of 1.9 times higher than larger Chlamydomonas (> $20 \mu \mathrm{m}$ diameter) (Fulton and Paerl 1987). Such feeding behavior of rotifers may compromise their nutritional requirements with toxin containing biopolymers, because cyanobacteria lack essential lipids. Hence, they are not suitable for fulfilling the nutritional requirement of zooplankton (mostly cladocerans and copepods) (Dickman et al. 2008). Unlike cyanobacteria, enzymatic digestion constraints are familiar in non-blue-green algae diet. These include gelatin and mucopolysaccharides in species like Sphaerocyetis, Scenedesmus and diatoms (Porter and Orcutt 1980). Knisely et al (1986) reported that in Lake Constance cladocerans, Daphnia hyalina and D. galeata grazed upon both coccoid and flagellates and but preferred the latter for nutritional requirement.

Cladocerans and rotifers mostly feed on filamentous algae, however, their feeding activity is inhibited by a cyanobacterial toxin named microcystin (Hairston 1999). Research investigations reveal that zooplankton can adapt to microcystin-containing cyanobacteria in their diet and develop or produce microcystin assimilation factors in their body (Hairston 1999; Sarnelle and Wilson 2005). In an experiment feeding zooplankton with microcystin diet, showed that microcystin minimized the growth rates of around $70 \%$ grazing population without any other detrimental effects (Sánchez et al. 2019). Zooplankton also known as filter feeders, feed more frequently on small chlorophytes and flagellates than cyanobacteria, which limits the toxin assimilating activities of zooplankton as copepods, cladocerans and rotifers. However, no statistically significant difference was found in regard to size and metabolism among the grazing populations feeding on both toxic algae and nontoxic algae (Wilson 2006). Toxic phytoplankton has been intrinsically diverse and often coexists with zooplankton communities (Kerfoot et al. 1985). An efficient mechanism of toxin dilution and compensatory feeding is observed in a dinoflagellate (Alexandrium minutum) that and a sympatric population of a copepod (Acartia clausi), when fed with a mixed diet of two varieties of $A$. minutum cells i.e., toxic and non-toxic, the toxic cells negatively influenced on ovipaity, egg hatching and overall total reproductive performance of Acartia clausi whereas the non-toxic cells had no impact on the life cycle of Acartia clausi (Lu" rling and Van Der Grinten 2003). However, in cladocerans as Daphnia sp., mortality rates increased after feeding on toxin producing cyanobacteria (Lampert 1981). Zooplankton have evolved over time and emerged as highly toxin tolerable species with toxin defence mechanisms (Tillmanns et al. 2008). Ger et al (2016) described some interesting zooplankton cyanotoxin tolerance traits and categorized depending on two factors - 1) grazing behaviour in relation to ingestion of number of cells containing toxins and 2) digestion and assimilation dynamics after intake of toxic metabolites (Kirk and Gilbert 1992; Pflugmacher et al. 1998). Therefore zooplankton may effectively reduce algal blooms and turbidity of water and help in transformation of trophic status of eutrophic water bodies.

\subsubsection{Biomanipulation involving mussels and snails}

Mussels are an important component of pisciculture and over the past few decades culture of mussels have been playing a key role in economic development in Australian and European countries. Mussels are a key species in biomanipulation studies and have been recognized due to their rapid filter feeding activities. Freshwater mussels remove seston (i.e., a collection of non-living material and living organisms) by its filter feeding activity and significantly reduce phytoplankton biomass to restore eutrophic waters. Echyridella menziesi, a fresh mussel can restore water clarity buying filter feeding on phytoplankton biomass (Ogilvie and Mitchell 1995). Dreissena rostriformis bugensis or Quagga is abundantly found in the Netherlands in lentic and lotic water bodies, it is fast growing bivalve and excellent filter feeder, used a tool controlling harmful algal blooms in urban ponds (Waajena 2016). Quagga mussels can clean hypertrophic waters and improve clarity of water. Another potential filter feeder 
Dreissena polymorpha or zebra mussels has been reported to clear eutrophic waters in a shallow temperate hypereutrophic lake. Zebra mussels is considered as a potential biomanipulation tool for improving water quality and reducing turbidity of eutrophic lakes (Richter 1986).

Snails can also help clearing turbidity of eutrophic waters, they are also known as scrapers because they ingest phytoplankton and organic matter growing on solid substrates (Alfaro et al. 2007). Bellamya aeruginosa, a freshwater snail commonly found in fresh water lakes, rivers, and ponds in China, can significantly reduce algal blooms in wetlands (Chase et al. 2006; Loman 2001). Stocking of the Lymnaea sp. (pulmonata snail) in eutrophic waters showed decline in cyanobacterial cell density, especially Microcystis aeruginosa (Jin 2015).

\section{Reinforcement Of Biomanipulation As An Eco-bioengineering Tool}

Biomanipulation is an emerging practice since the past century and it has been globally recognized as a pioneering tool in managing eutrophic water bodies. Biomanipulation was reinforced as eco-bioengineering for the first time by Shapiro et al (1975), as it included modification species composition or rearrangement of species by manipulating fishes, zooplankton, harmful algae and aquatic biomass, and overall reduction in nutrient load (Wetzel 2001). Jones (1986) considered biomanipulation as a relatively new technique performed by removing some fish species and restructuring plankton communities to enhance water transparency of eutrophic lakes. With the advent of new concepts and technological development in the field of biomanipulation studies, researchers have reintroduced biomanipulation as an ecohydrological approach in treating water bodies under eutrophication and environmental pollution stress. Biomanipulation has evolved over several decades and adapted to innovative ecohydrological practices and attained better results than the traditional biomanipulation methods. In the immediate decade i.e., 2010 to 2020, the flux of bioengineering research is concentrated in two areas - classical biomanipulation studies (81.25\%) and non-classical or advanced eco-bioengineering studies (18.75\%). A worldwide online literature survey revealed that most of the biomanipulation research is pocketed in Europe and East Asian regions followed by North America, South America, South Africa and Oceania (Fig. 4). This signifies the crucial role of environmental factors, climate change agents and anthropogenic agents in inducing eutrophication of water bodies and the response to risk assessment and risk analysis with a prompt scientific outlook.

Eco-bioengineering methods vis-à-vis non-classical or advanced biomanipulation methods are often conducted in amalgamation with eco-computational models based on current investigations or reconstruction of old age database, and a physical or chemical agent or a bio-engineered agent to obtain sustainable outcomes (Shapiro et al. 1975; He et al. 2011; Hobbs et al. 2012; Lewtas et al. 2015). He et al. 2011 reported a series of ecohydrological inputs including biomanipulation in a three-dimensional eutrophication model to reduce eutrophication in Beijing Guanting Reservoir, China. Eco-bioengineering enhances classical biomanipulation methods by combining it with technical interventions of nutrient $(N, P)$ retention and prevention of nutrient release from sediments and internal nutrient transfer processes (Søndergaard et al. 2013). Advanced biomanipulation practices involve manipulation of biological agents combined with non-biological agents like addition of biological products (barley straw) and chemicals (alum, rotenone), and physical treatment (draining, dredging), and reconstruction of previous environmental conditions by modelling nutrient dynamics and ecological dynamics (Mustapha 2010; Webber 2014; He et al. 2011). In innovative eco-bioengineering methods, nutrient (C, N, and P) and chlorophyll-a are not always considered as key eutrophication drivers, some unique features like algal biomass, sprat spawning stock biomass (SSB), pesticides, organic pollutants, hydrochemical variables and the whole ecological niche may modulate water quality, DO levels, nutrient enrichment, chlorophyll-a levels and exacerbation of nutrients and trophic status 
(Lindegren et al. 2010; Skov et al. 2019, Sharma 2015; Sharma et al. 2010; Bernes et al. 2013). A list of ecobioengineering approaches and their effective outcomes are detailed in Table.

\subsubsection{Success rates of biomanipulation and non-recurrence of eutrophication}

In classical methods of biomanipulation, success rates may vary depending upon the geomorphic features, duration, and nature of treatment (Figure). Eutrophication recurrence episodes are common and therefore, upgradation of conventional biomanipulation methods and identification of the loopholes will help in amplifying the success rates of manipulation of biotic species. Jepessen et al (2012) categorized biomanipulation into seven different ways to highlight successful biomanipulation and non-recurrence of eutrophication in target water bodies. Removal of zooplanktivorous and benthivorous fishes may lead to successful and long-term stability in shallow and warm temperate eutrophic lakes (Jeppesen et al. 2005; Søndergaard et al. 2007). Berg et al (1997) reports that stocking of piscivorous fishes (e.g., pike) also increases the success rates of biomanipulation in Lake Lyng, Denmark in absence of some of other pelagic predator fishes (e.g., perch). Sometimes fish introduction or removal leads to only partial success of biomanipulation with a challenging prospect of reappearance of excessive nutrient load, chlorophyll-a, and turbidity in the water (Xie et al. 2001). Classical biomanipulation involving removal or introduction of zooplankton and macrophytes also improves the viability and long-term effectiveness of a modified food-web structure in the aquatic systems (Moore et al. 2010). However, abiotic factors as nutrient-sediment dynamics and sustainability of biomanipulation experiments indicate whether the ecological resilience in response to eutrophication is strong and recurrence is completely prevented (Søndergaard et al. 2007). Recurrence rates of eutrophication depend on the consistency of the treatment methods and most of the non-classical biomanipulation techniques have been upgraded with an ecohydrological perspective to obtain an ecologically balanced system. Eco-bioengineering methods will help in reducing recurrence of eutrophication events and fulfilling successful biomanipulation that will sustain for a long period of time and withstand any future ecological imbalances (Table). 5.1.2. Cost-benefit analysis of eco-bioengineering methods

Eco-bioengineering methods are based on cost-effective risk assessment and analysis to mitigate the extremities of eutrophication. It has been suggested that in-vitro management of biological agents and transfer of the optimized technology to in-vivo conditions will help in minimizing the cost of direct in-situ biomanipulation undertakings (reference). Size optimization of enclosures or the in-situ water bodies for conducting biomanipulation experiments has been found to be effective in reducing the cost of restoration studies (Godwin et al. 2011). Jeppesen et al. (2012) uphold the effectiveness of innovative biomanipulation methods in obtaining both short-term and long-term benefits. They coined that eco-bioengineering methods generally reduces the restoration costs for treatment of eutrophic water bodies. Short-term classical biomanipulation experiments may also be cost-effective but the main goal (i.e., attainment of permanent and sustainable restoration) may not be enough to justify the costs of biomanipulation (Hobbs et al. 2012; Hansson et al. 1998).

There are instances of very expensive classical biomanipulation projects like the Hartbeespoort Dam Bioremediation Programme (HDBP) in south African reservoirs costing up to R100 millionyr ${ }^{-1}$ (approximately US\$ 8.5 million), realizing the need of a continual and sustainable approach instead of costly therapeutic tools for managing eutrophication (Hart and Harding 2015). Large scale pilot projects may be managed with optimal costs, Lewtas et al (2015) conducted a combined classical biomanipulation and eco-bioengineering restoration of Twin Lake, Minnesota at minimal cost and presented a detailed cost-analysis report of for their pilot project. This report motivates researchers to adopt inexpensive combined restoration technologies in the long run and obtain costeffective results with fundamental infrastructures and eco-friendly biophysicochemical agents. Successful biomanipulation studies involving biological agents like barley straw showed cost-effective results with a small capital amount for treating eutrophic reservoirs in African provinces (Mustapha 2010). Biomanipulation

Page 10/30 
experiments enhanced with ecohydrological approaches will always provide a sustainable and positive cost-benefit platform to treat water bodies over conventional methods involving costly ex-situ treatment or equipment analysis and other externalities (Jurajda et al. 2016).

\section{Conclusion, Research Gap, And Future Prospects}

Eutrophication is an emerging environmental crisis and our study focusses on restoration of eutrophic waters using ecohydrological approaches of classical biomanipulation and innovative eco-bioengineering methods. This review paper critically examines the role biomanipulation in historical as well as current research endeavours i.e., rehabilitation of eutrophic water bodies. Comprehensive literature review showed the pathways of reform of earliest biomanipulation methods into new eco-bioengineering tools (Shapiro et al. 1975; Mannina et al. 2020). Classical biomanipulation methods have been successful over a wide range of environmental and geographic conditions, however, these approaches may not be effective in maintaining long-term stability of restored water bodies or preventing recurrence of eutrophication. These biomanipulation techniques are improved by blending them with eco-friendly biophyiscochemical agents or extrapolating databases with the help of ecological models to predict the future consequences. Researchers have observed the effect of classical biomanipulation on ecosystem functions as doubtful because it lacks a multidirectional approach in dealing with diverse ecological communities in aquatic system (Jeppesen et al. 2012). This review investigation presents a holistic approach towards addressing the research gaps in classical biomanipulation practices and endorsing advanced ecohydrological methods in filling these breaches i.e., by promoting eco-bioengineering tools. In purview of the "state of the art" scenario of biomanipulation techniques, the following research conclusions and future recommendations have been summarized:

- At a global scale, classical biomanipulations have been practiced to rehabilitate eutrophic waters. However, the success rates and eutrophication recurrence events are uncertain. Eco-bioengineering methods combined with ecological models would help to extrapolate, predict, trace, and modulate the dynamic environmental variables that play crucial role in accomplishing self-sufficient biomanipulation practice.

- Classical biomanipulations lack comprehensiveness in regard to reproducibility and efficiency; while innovative biophysicochemical amendments facilitate in increasing longevity and efficacy of the restoration techniques at micro- and macrolevel ecosystems.

- A worldwide literature survey reveals a current trend of biomanipulation research distributed in Europe (43.48\%), East Asia (34.78\%), North America (8.70\%), South America (2.90\%), South Africa (4.35\%), Oceania (1.45\%), Middle East (1.45\%) and non-specific regions (2.90\%). This data provide a scope for uniform propagation and outreach of ecohydrological approaches and eco-bioengineering methods to provide sustainable solutions on global scale.

- Classical biomanipulation methods may be challenged by their potentiality to treat a wide range of eutrophic water bodies located in the subtropics and tropics due to accessibility issues and economic feasibility. On the other hand, eco-bioengineering methods are cost-effective green technologies that may be practiced in any part of the world following a sustainable and positive cost-benefit approach to restore eutrophic water bodies, without compromising the ecological health of aquatic communities.

- Early biomanipulation studies may lack totality in terms of irreversible restoration of affected water bodies. Therefore, innovation of classical biomanipulation techniques will help in actively responding to environmental flows and building a strong ecological resilience to defy recurrence events of eutrophication in future. 
- Eco-bioengineering methods involve manipulation of the food chain or food web and mediate change in trophic status of aquatic ecosystems. Effective polyculture combinations like planktivores fishes, macrophytes and mussels can help in developing an efficient in-situ optimized biomanipulation technology combined with biophysicochemical and computational support.

- Finally, this review presents a baseline for technical innovations in biomanipulation studies for future endeavours and policy making to encourage exponential research and development in the field of ecohydrology.

\section{DECLARATION (CONFLICT OF INTEREST)}

The authors hereby declare that there are no personal relationships or financial interests that could influence the preparation and publication of the manuscript. 
Table 1

Innovative biomanipulation vis-à-vis eco-bioengineering for sustainable and long-term restoration of eutrophic water bodies

\begin{tabular}{|c|c|c|c|c|c|}
\hline Description & Key Species & Key drivers & Target feature & Location & References \\
\hline $\begin{array}{l}\text { Biomanipulation } \\
\text { of microbial } \\
\text { pathogens, } \\
\text { aquatic } \\
\text { macrophytes } \\
\text { and fishes } \\
\text { combined with } \\
\text { Barley straw } \\
\text { treatment to } \\
\text { eutrophic waters }\end{array}$ & $\begin{array}{l}\text { Fishes } \\
\text { (Tilapia, } \\
\text { Heterotis, } \\
\text { Synodontis } \\
\text { etc.), } \\
\text { zooplankton } \\
\text { (Daphnia and } \\
\text { Bosmina), } \\
\text { virus, bacteria, } \\
\text { fungi and } \\
\text { protozoa, } \\
\text { macrophytes } \\
\text { and barley } \\
\text { straw }\end{array}$ & Algal biomass & Phytoplankton & $\begin{array}{l}\text { African } \\
\text { reservoirs, } \\
\text { South Africa }\end{array}$ & Mustapha 2010 \\
\hline $\begin{array}{l}\text { Biomanipulation } \\
\text { in polluted lake } \\
\text { using northern } \\
\text { pike }\end{array}$ & $\begin{array}{l}\text { Northern } \\
\text { Pike (Esox } \\
\text { lucius) }\end{array}$ & $\begin{array}{l}\text { DDT, PCB, HCB } \\
\text { and HCE }\end{array}$ & $\begin{array}{l}\text { Zooplankton, } \\
\text { macroinvertebrates, } \\
\text { and fish }\end{array}$ & $\begin{array}{l}\text { Lake } \\
\text { årungen, } \\
\text { Norway, } \\
\text { Europe }\end{array}$ & $\begin{array}{l}\text { Sharma et al } \\
2010\end{array}$ \\
\hline $\begin{array}{l}\text { Biomanipulation } \\
\text { of planktivorous } \\
\text { fishes to restore } \\
\text { eutrophic waters }\end{array}$ & $\begin{array}{l}\text { Planktivorous } \\
\text { fishes (cod } \\
\text { and sprat) }\end{array}$ & $\begin{array}{l}\text { Sprat } \\
\text { spawning } \\
\text { stock biomass } \\
\text { (SSB) }\end{array}$ & Phytoplankton & $\begin{array}{l}\text { Narrow } \\
\text { straits and } \\
\text { shallow sills } \\
\text { in Baltic } \\
\text { Sea, } \\
\text { Denmark, } \\
\text { Europe }\end{array}$ & $\begin{array}{l}\text { Lindegren et al } \\
2010\end{array}$ \\
\hline $\begin{array}{l}\text { Biomanipulation } \\
\text { by changing the } \\
\text { feeding habits } \\
\text { of fishes in } \\
\text { reservoirs }\end{array}$ & $\begin{array}{l}\text { Fish (Abramis } \\
\text { brama) }\end{array}$ & Zooplankton & $\begin{array}{l}\text { Macrophytes, } \\
\text { benthic } \\
\text { macroinvertebrates } \\
\text { and zooplankton }\end{array}$ & $\begin{array}{l}\text { Hamry } \\
\text { reservoir in } \\
\text { River } \\
\text { Chrudimka, } \\
\text { Czech } \\
\text { Republic, } \\
\text { Europe }\end{array}$ & $\begin{array}{l}\text { Zapletal et al } \\
2012\end{array}$ \\
\hline $\begin{array}{l}\text { Biomanipulation } \\
\text { of fishes to } \\
\text { reduce } \\
\text { phosphorus } \\
\text { loadings from } \\
\text { groundwater to } \\
\text { a eutrophic } \\
\text { seepage lake }\end{array}$ & $\begin{array}{l}\text { Cyprinid } \\
\text { fishes }\end{array}$ & TP & $\begin{array}{l}\text { Total phosphorus } \\
\text { loadings }\end{array}$ & $\begin{array}{l}\text { Lake Væng, } \\
\text { Denmark, } \\
\text { Europe }\end{array}$ & $\begin{array}{l}\text { Kidmose et al } \\
2013\end{array}$ \\
\hline $\begin{array}{l}\text { Biomanipulation } \\
\text { of fishes to } \\
\text { reduce P release } \\
\text { form sediment } \\
\text { in eutrophic } \\
\text { lakes }\end{array}$ & Fishes & $\begin{array}{l}\text { TP, chlorophyll- } \\
\text { a }\end{array}$ & $\begin{array}{l}\text { Total phosphorus } \\
\text { from sediments }\end{array}$ & $\begin{array}{l}\text { Lakes in } \\
\text { Denmark, } \\
\text { Europe }\end{array}$ & $\begin{array}{l}\text { Søndergaard et } \\
\text { al. } 2013\end{array}$ \\
\hline
\end{tabular}




\begin{tabular}{|c|c|c|c|c|c|}
\hline Description & Key Species & Key drivers & Target feature & Location & References \\
\hline $\begin{array}{l}\text { Biomanipulation } \\
\text { in temperate } \\
\text { eutrophic lakes } \\
\text { involving } \\
\text { planktivorous } \\
\text { and } \\
\text { benthivorous } \\
\text { fish, a review }\end{array}$ & $\begin{array}{l}\text { Planktivorous } \\
\text { and } \\
\text { benthivorous } \\
\text { fish }\end{array}$ & $\begin{array}{l}\text { Nutrients, lake } \\
\text { salinity and } \\
\text { conductivity } \\
\text { water colour, } \\
\text { DOC etc. }\end{array}$ & $\begin{array}{l}\text { Zooplankton, } \\
\text { phytoplankton }\end{array}$ & $\begin{array}{l}\text { Temperate } \\
\text { eutrophic } \\
\text { lakes, } \\
\text { Generic }\end{array}$ & $\begin{array}{l}\text { Bernes et ql } \\
2013\end{array}$ \\
\hline Description & Key Species & Key drivers & Target feature & Location & References \\
\hline $\begin{array}{l}\text { Treatment of } \\
\text { eutrophic lakes } \\
\text { by alum and } \\
\text { Biomanipulation } \\
\text { Dual } \\
\text { Treatment }\end{array}$ & Cyanobacteria & $\begin{array}{l}\text { TP, TN, } \\
\text { chlorophyll-a, } \\
\text { pH, } \\
\text { microcystin }\end{array}$ & HABs & $\begin{array}{l}\text { Fremont } \\
\text { Lakes State } \\
\text { Recreation } \\
\text { Area, } \\
\text { Nebraska, } \\
\text { USA North } \\
\text { America }\end{array}$ & Webber 2014 \\
\hline $\begin{array}{l}\text { Biomanipulation } \\
\text { of snail to } \\
\text { reduce algal } \\
\text { blooms in } \\
\text { eutrophic ponds }\end{array}$ & $\begin{array}{l}\text { Snail } \\
\text { (Lymnaea sp.) }\end{array}$ & Phytoplankton & $\begin{array}{l}\text { HABs (Microcystis } \\
\text { aeruginosa) }\end{array}$ & $\begin{array}{l}\text { Ponds in } \\
\text { Jiangsu } \\
\text { Province, } \\
\text { China, East } \\
\text { Asia }\end{array}$ & Jin et al 2014 \\
\hline $\begin{array}{l}\text { Biomanipulation } \\
\text { of fishes by } \\
\text { capturing fishes } \\
\text { with traditional } \\
\text { anglers in } \\
\text { reservoirs }\end{array}$ & $\begin{array}{l}\text { Fishes } \\
\text { (common } \\
\text { carp, } \\
\text { Goldfish and } \\
\text { bleak) }\end{array}$ & TP, TN & $\begin{array}{l}\text { Total phosphorus } \\
\text { and Total Nitrogen } \\
\text { loadings }\end{array}$ & $\begin{array}{l}\text { Reservoirs } \\
\text { in Southern } \\
\text { Portugal, } \\
\text { Europe }\end{array}$ & $\begin{array}{l}\text { Amaral et al } \\
2015\end{array}$ \\
\hline $\begin{array}{l}\text { Biomanipulation } \\
\text { of fishes to } \\
\text { reduce total } \\
\text { phosphorus in } \\
\text { eutrophic waters }\end{array}$ & $\begin{array}{l}\text { Fishes } \\
\text { (catfish and } \\
\text { carp) }\end{array}$ & TP & TP loadings & $\begin{array}{l}7 \text { South } \\
\text { African } \\
\text { reservoirs, in } \\
\text { Gauteng, } \\
\text { North West } \\
\text { and } \\
\text { Limpopo } \\
\text { provinces, } \\
\text { South Africa }\end{array}$ & $\begin{array}{l}\text { Hart and } \\
\text { Harding } 2015\end{array}$ \\
\hline $\begin{array}{l}\text { Biomanipulation } \\
\text { involving fish to } \\
\text { reduce } \\
\text { persistent } \\
\text { organic } \\
\text { pollutants }\end{array}$ & $\begin{array}{l}\text { Fish (Northern } \\
\text { pike, Esox } \\
\text { lucius L.) }\end{array}$ & $\begin{array}{l}\text { Mercury and } \\
\text { persistent } \\
\text { organochlorine }\end{array}$ & Fish & $\begin{array}{l}\text { Lake } \\
\text { Årungen, } \\
\text { Norway } \\
\text { Europe }\end{array}$ & Sharma 2015 \\
\hline $\begin{array}{l}\text { Manipulation of } \\
\text { diets in mussels } \\
\text { in relation to } \\
\text { removal of algal } \\
\text { toxins }\end{array}$ & $\begin{array}{l}\text { Mussels } \\
\text { (Anodonta } \\
\text { woodiana) }\end{array}$ & Chlorophyll a & $\begin{array}{l}\text { Algal toxins } \\
\text { (Microcystis } \\
\text { aeruginosa and } \\
\text { Scenedesmus } \\
\text { obliquus) }\end{array}$ & $\begin{array}{l}\text { Lake Taihu, } \\
\text { China, East } \\
\text { Asia }\end{array}$ & Liu 2014 \\
\hline
\end{tabular}




\begin{tabular}{|c|c|c|c|c|c|}
\hline Description & Key Species & Key drivers & Target feature & Location & References \\
\hline $\begin{array}{l}\text { Biomanipulation } \\
\text { in eutrophic } \\
\text { urban ponds } \\
\text { using Quagga } \\
\text { mussels, } \\
\text { zooplankton } \\
\text { and } \\
\text { phytoplankton }\end{array}$ & $\begin{array}{l}\text { Quagga } \\
\text { mussels } \\
\text { (Dreissena } \\
\text { rostriformis } \\
\text { bugensis) }\end{array}$ & $\begin{array}{l}\text { TN, TP, } \\
\text { chlorophyll-a, } \\
\text { suspended } \\
\text { solids, pH etc. }\end{array}$ & $\begin{array}{l}\text { Zooplankton } \\
\text { (Leptodora kindtii, } \\
\text { Naupliisp. etc.) } \\
\text { and HABs } \\
\text { (Scenedesmus } \\
\text { obliquus } \\
\text { Microcystis } \\
\text { aeruginosa) }\end{array}$ & $\begin{array}{l}\text { Urban } \\
\text { ponds in } \\
\text { The } \\
\text { Netherlands, } \\
\text { Europe }\end{array}$ & $\begin{array}{l}\text { Waajen et al } \\
2016\end{array}$ \\
\hline Description & Key Species & Key drivers & Target feature & Location & References \\
\hline $\begin{array}{l}\text { Biomanipulation } \\
\text { of tropical } \\
\text { eutrophic lakes } \\
\text { by removal of } \\
\text { fishes and } \\
\text { transplantation } \\
\text { of macrophyte }\end{array}$ & $\begin{array}{l}\text { Fishes and } \\
\text { macrophytes }\end{array}$ & $\begin{array}{l}\text { TP, chlorophyll- } \\
\text { a }\end{array}$ & Nutrient dynamics & $\begin{array}{l}\text { Huizhou } \\
\text { West Lake, } \\
\text { China, East } \\
\text { Asia }\end{array}$ & $\begin{array}{l}\text { Jensen et al } \\
2016\end{array}$ \\
\hline $\begin{array}{l}\text { In-vitro } \\
\text { biomanipulation } \\
\text { of zooplankton } \\
\text { and } \\
\text { phytoplankton } \\
\text { for potential } \\
\text { treatment of } \\
\text { eutrophication }\end{array}$ & $\begin{array}{l}\text { Zooplankton } \\
\text { (Cladocera, } \\
\text { Copepoda } \\
\text { and } \\
\text { Ostracoda) }\end{array}$ & Algal cells & $\begin{array}{l}\text { Phytoplankton } \\
\text { (Chlorella sp., } \\
\text { Crucigenia sp., } \\
\text { Scenedesmus sp., } \\
\text { Monoraphidium } \\
\text { sp.) }\end{array}$ & $\begin{array}{l}20 \\
\text { reservoirs, } \\
\text { Sri Lanka }\end{array}$ & $\begin{array}{l}\text { Wickramasinghe } \\
\text { and } \\
\text { Yatigammana } \\
2017 f\end{array}$ \\
\hline $\begin{array}{l}\text { Biomanipulation } \\
\text { using fishes and } \\
\text { phytoplankton } \\
\text { using a food } \\
\text { web model to } \\
\text { construct a } 10 \\
\text { year } \\
\text { biomanipulation } \\
\text { management } \\
\text { scenario }\end{array}$ & $\begin{array}{l}\text { St. Peter's fish, } \\
\text { mugilids, } \\
\text { mugil and } \\
\text { silver carp }\end{array}$ & $\begin{array}{l}\text { Phytoplankton } \\
\text { and } \\
\text { zooplankton }\end{array}$ & $\begin{array}{l}\text { Zooplankton, } \\
\text { phytoplankton } \\
\text { (Aphanizomen, } \\
\text { Aulacosira, } \\
\text { Microcystis, } \\
\text { Peridinium, } \\
\text { Debarya) } \\
\text { and nanoplankton }\end{array}$ & $\begin{array}{l}\text { Lake } \\
\text { Kinneret, } \\
\text { Middle East }\end{array}$ & Ofir et al 2017 \\
\hline $\begin{array}{l}\text { Biomanipulation } \\
\text { of cyprinid } \\
\text { fishes to restore } \\
\text { eutrophic lake }\end{array}$ & $\begin{array}{l}\text { Cyprinid } \\
\text { fishes }\end{array}$ & $\begin{array}{l}\text { Habitating of } \\
\text { cyprinid fishes }\end{array}$ & Clarity of water & $\begin{array}{l}\text { Lake Søga } \\
\text { rd and a } \\
\text { Danish lake, } \\
\text { Denmark }\end{array}$ & Skov et al 2019 \\
\hline $\begin{array}{l}\text { Biomanipulation } \\
\text { of fishes } \\
\text { combined with } \\
\text { physical } \\
\text { treatment in } \\
\text { eutrophic lake }\end{array}$ & $\begin{array}{l}\text { Fishes (pike } \\
\text { and pikeperch } \\
\text { fry) }\end{array}$ & $\begin{array}{l}\text { TP, chlorophyll- } \\
\text { a }\end{array}$ & Cyanobacteria & $\begin{array}{l}\text { Swarze } \\
\text { \dzkie Lake, } \\
\text { Poland }\end{array}$ & $\begin{array}{l}\text { Kowalczewska- } \\
\text { Madura et al } \\
2020\end{array}$ \\
\hline \multicolumn{6}{|c|}{$\begin{array}{l}\text { TP-Total Phosphorus; TN-Total Nitrogen; DOC- Dissolved Organic Carbon; PCB-polychlorinated biphenyls; HCB- } \\
\text { hexachlorobenzene; HCE-heptachlor epoxide; DDTs-Dichlorodiphenyltrichloroethane; HABs-Harmful algal } \\
\text { blooms }\end{array}$} \\
\hline
\end{tabular}

\section{Declarations}


The authors hereby declare that there are no personal relationships or financial interests that could influence the preparation and publication of the manuscript.

\section{ACKNOWLEDGEMENT}

The authors are grateful to Science and Engineering Research Board (SERB) (File No. ECR/2018/002481) for financial support and technical support

\section{References}

1. Adámek Z, Mikl L, Šlapanský L, Jurajda P, \& Halačka K (2019) The diet of predatory fish in drinking water reservoirs-how can they contribute to biomanipulation efforts? Journal of Vertebrate Biology 68(4): 215-224.

2. Alfaro AC, Dewas SE, \& Thomas F (2007) Food and habitat partitioning in grazing snails (Turbo smaragdus), Northern New Zealand. Estuaries and coasts 30(3): 431-440.

3. Amaral SD, Franco A, \& Ferreira MT (2015) Moderate biomanipulation for eutrophication control in reservoirs using fish captured in angling competitions. Knowledge and Management of Aquatic Ecosystems (416): 14.

4. Anderson DM (2009) Approaches to monitoring, control and management of harmful algal blooms (HABs). Ocean \& coastal management 52(7): 342-347.

5. Andersson, G, Berggren H, Cronberg G, \&Gelin C (1978) Effects of planktivorous and benthivorous fish on organisms and water chemistry in eutrophic lakes. Hydrobiologia 59(1): 9-15

6. Arend KK, Beletsky D, DePINTO JV, Ludsin SA, Roberts JJ, Rucinski DK, ... \&Höök TO (2011) Seasonal and interannual effects of hypoxia on fish habitat quality in central Lake Erie. Freshwater Biology 56(2): 366-383.

7. Arlinghaus R, Lorenzen K, Johnson BM, Cooke SJ, \&Cowx IG (2016) Management of freshwater fisheries: addressing habitat, people and fishes. Freshwater fisheries ecology 1: 557-559.

8. Barko JW \& James WF (1998) Effects of submerged aquatic macrophytes on nutrient dynamics, sedimentation, and resuspension. In The structuring role of submerged macrophytes in lakes 197-214. Springer, New York, NY.

9. Benndorf J, Kneschke H, Kossatz K, \&Penz E (1984) Manipulation of the pelagic food web by stocking with predacious fishes. Internationale Revue der gesamtenHydrobiologie und Hydrographie 69(3): 407-428.

10. Benndorf J, Wissel B, Sell AF, Hornig U, Ritter P, \&Böing W (2000) Food web manipulation by extreme enhancement of piscivory: an invertebrate predator compensates for the effects of planktivorous fish on a plankton community. Limnologica 30(3): 235-245.

11. Berdalet E, Fleming LE, Gowen R, Davidson K Hess P, Backer LC, \& Enevoldsen H (2016) Marine harmful algal blooms, human health and wellbeing: challenges and opportunities in the 21 st century. Journal of the Marine Biological Association of the United Kingdom 96(1): 61-91.

12. Berg S, Jeppesen E, \& Søndergaard M (1997) Pike (Esox lucius L.) stocking as a biomanipulation tool 1. Effects on the fish population in Lake Lyng, Denmark. In Shallow Lakes' 95: 311-318. Springer, Dordrecht.

13. Bernes C, Carpenter SR, Gårdmark A, Larsson P, Persson L, Skov C, \& Van Donk E (2013) What is the influence on water quality in temperate eutrophic lakes of a reduction of planktivorous and benthivorous fish? A systematic review protocol. Environmental Evidence 2(1): 1-8.

14. Blindow I, Andersson G, Hargeby A, \& Johansson S (1993) Long term pattern of alternative stable states in two shallow eutrophic lakes. Freshwater Biology 30(1): 159-167. 
15. Bogdan KG, \& McNaught DC (1975) Selective feeding by Diaptomus and Daphnia: With 4 figures and 3 tables in the text. Internationale Vereinigung für theoretische und angewandte Limnologie: Verhandlungen 19(4): 2935-2942.

16. Bonneau JL, \& Scarnecchia DL (2015) Response of benthic macroinvertebrates to carp (Cyprinus carpio) biomanipulation in three tributaries of a eutrophic, Great Plains reservoir, USA. Transactions of the Kansas Academy of Science 118(1-2): 13-26.

17. Carey RO, \& Migliaccio KW (2009) Contribution of wastewater treatment plant effluents to nutrient dynamics in aquatic systems: a review. Environmental Management 44(2): 205-217.

18. Carignan R, \& Kalff J (1980) Phosphorus sources for aquatic weeds: water or sediments? Science 207(4434): 987-989.

19. Carmichael WW (2001) A mini-review of cyanotoxins: toxins of cyanobacteria (blue-green algae). Microcystin and phycotoxins in perspective and the turn of the millennium. Ponson\&Looyen, Wageningen, The Netherlands 495-504.

20. Carpenter SR (1981) Submersed vegetation: an internal factor in lake ecosystem succession. Th e America $\mathrm{n}$ Naturalist 118(3): 372-383.

21. Carpenter SR, Caraco NF, Correll DL, Howarth RW, Sharpley AN, \& Smith VH (1998) Nonpoint pollution of surface waters with phosphorus and nitrogen. Ecological applications 8(3): 559-568.

22. Carpenter SR, Kitchell F, Hodgson R, Cochran PA, Elser DM, Kretchmer D, \& von Ende CN (1987). Promoting the Science of Ecology. Ecology 68(6): 1863-1876.

23. Chase JM, \& Knight TM (2006) Effects of eutrophication and snails on Eurasian watermilfoil (Myriophyllum spicatum) invasion. Biological Invasions 8(8): 1643.

24. Christoffersen K, Riemann B, Klysner A, \&Søndergaard M (1993) Potential role of fish predation and natural populations of zooplankton in structuring a plankton community in eutrophic lake water. Limnology and Oceanography 38(3): 561-573.

25. Dickman EM, Newell JM, González MJ, \& Vanni MJ (2008) Light, nutrients, and food-chain length constrain planktonic energy transfer efficiency across multiple trophic levels. Proceedings of the National Academy of Sciences 105(47): 18408-18412.

26. Dionisio Pires LM, Bontes BM, Van Donk E, \& Ibelings BW (2005) Grazing on colonial and filamentous, toxic and non-toxic cyanobacteria by the zebra mussel Dreissena polymorpha. Journal of Plankton Research 27(4): 331 339.

27. Drenner RW \& Hambright KD (1999) Biomanipulation of fish assemblages as a lake restoration technique Archiv für Hydrobiologie, 129-165.

28. Fulton RS, \& Paerl HW (1987) Toxic and inhibitory effects of the blue-green alga Microcystis aeruginosa on herbivorous zooplankton. Journal of Plankton Research 9(5): 837-855.

29. Ger KA, Urrutia-Cordero P, Frost PC, Hansson LA, Sarnelle O, Wilson AE, \&Lürling M (2016) The interaction between cyanobacteria and zooplankton in a more eutrophic world. Harmful algae 54: 128-144

30. Gladyshev MI, Chuprov SM, Kolmakov VI, Dubovskaya OP, Zadorin AA, Zuev IV, ... \& Kravchuk ES (2003). A biomanipulation bypassing the trophic cascade in a small reservoir. In Doklady Biological Sciences 390:235237.

31. Godwin W, Coveney M, Lowe E, \& Battoe L (2011) Improvements in water quality following biomanipulation of gizzard shad (Dorosoma cepedianum) in Lake Denham, Florida. Lake and Reservoir Management 27(4): 287- 
297.

32. González-Bergonzoni I, Meerhoff M, Davidson TA, Teixeira-de Mello F, Baattrup-Pedersen A, \& Jeppesen E (2012) Meta-analysis shows a consistent and strong latitudinal pattern in fish omnivory across ecosystems. Ecosystems 15(3): 492-503.

33. Hairston NG, Lampert W, Cáceres CE, Holtmeier CL, Weider LJ, Gaedke U, ... \& Post DM (1999) Rapid evolution revealed by dormant eggs. Nature 401(6752): 446-446.

34. Hansson L A, Annadotter H, Bergman E, Hamrin SF, Jeppesen E, Kairesalo T, ... \& Strand J (1998) Biomanipulation as an application of food-chain theory: constraints, synthesis, and recommendations for temperate lakes. Ecosystems 1(6): 558-574.

35. Hargrave BT, \& Geen GH (1970) Effects of copepod grazing on two natural phytoplankton populations. Journal of the Fisheries Board of Canada 27(8): 1395-1403

36. Hart RC, \& Harding WR (2015) Impacts of fish on phosphorus budget dynamics of some SA reservoirs: evaluating prospects of 'bottom up'phosphorus reduction in eutrophic systems through fish removal (biomanipulation). Water SA 41(4):432-440.

37. He G, Fang H, Bai S, Liu X, Chen M, \& Bai J (2011) Application of a three-dimensional eutrophication model for the Beijing Guanting Reservoir, China. Ecological Modelling 222(8): 1491-1501.

38. Hobbs WO, Hobbs JMR, LaFrançois T, Zimmer KD, Theissen KM, Edlund MB, ... \& Carlson TJ (2012) A 200-year perspective on alternative stable state theory and lake management from a biomanipulated shallow lake. Ecological Applications 22(5): 1483-1496.

39. Huisman J, Codd GA, Paerl HW, Ibelings BW, Verspagen JM, \& Visser PM (2018) Cyanobacterial blooms. Nature Reviews Microbiology 16(8): 471-483.

40. Jaynes ML, \& Carpenter SR (1986) Effects of vascular and nonvascular macrophytes on sediment redox and solute dynamics. Ecology 67(4): 875-882.

41. Jensen M, Liu Z, Zhang X, Reitzel K., \& Jensen HS (2017) The effect of biomanipulation on phosphorus exchange between sediment and water in shallow, tropical Huizhou West Lake, China. Limnologica 63: 65-73.

42. Jeppesen E, Jensen JP, Soendergaard M, \& Lauridsen TL (2005) Response of fish and plankton to nutrient loading reduction in eight shallow Danish lakes with special emphasis on seasonal dynamics. Freshwater Biology 50(10): 1616-1627.

43. Jeppesen E, Meerhoff M, Jacobsen BA, Hansen RS, Søndergaard M, Jensen JP, \& Branco CWC (2007) Restoration of shallow lakes by nutrient control and biomanipulation-the successful strategy varies with lake size and climate. Hydrobiologia 581(1): 269-285.

44. Jeppesen E, Søndergaard M, Søndergaard M, \& Christoffersen K (2012) The structuring role of submerged macrophytes in lakes (Vol. 131). Springer Science \& Business Media

45. Jin C, Liang Y, Liu S, Wu S, Qian X, \& Zhou X (2015) The pulmonata snail Lymnaea is a potential biomanipulation species for use against cyanobacteria blooms. Journal of Freshwater Ecology 30(4): 479-490

46. Jones WW (1986) The role of biomanipulation in fisheries management. Lake and Reservoir Management 2(1): 49-53.

47. Jurajda P, Adámek Z, Janáč M, Roche K, Mikl L, Rederer L, ... \&Špaček J (2016) Use of multiple fish-removal methods during biomanipulation of a drinking water reservoir-evaluation of the first four years. Fisheries Research 173: 101-108. 
48. Karjalainen J, Leppä M, Rahkola M, \&Tolonen K (1999) The role of benthivorous and planktivorous fish in a mesotrophic lake ecosystem. In Shallow Lakes' 98 : 73-84. Springer, Dordrecht.

49. Kerfoot WC, DeMott WR, \& DeAngelis DL (1985) Interactions among cladocerans: food limitation and exploitative competition. Arch. Hydrobiol. Beih. Ergebn. Limnol 21: 431-451.

50. Kidmose J, Nilsson B, Engesgaard P, Frandsen M, Karan S, Landkildehus F, ... \& Jeppesen E (2013) Focused groundwater discharge of phosphorus to a eutrophic seepage lake (Lake Væng, Denmark): implications for lake ecological state and restoration. Hydrogeology Journal 21(8): 1787-1802.

51. Kirk KL, \& Gilbert JJ (1992) Variation in herbivore response to chemical defenses: zooplankton foraging on toxic cyanobacteria. Ecology 73(6): 2208-2217.

52. Knisely K, \& Geller W (1986) Selective feeding of four zooplankton species on natural lake phytoplankton. Oecologia 69(1): 86-94.

53. Kowalczewska-Madura K, Rosińska J, Dondajewska-Pielka R, Gołdyn R, \& Kaczmarek L (2020) The Effects of Limiting Restoration Treatments in a Shallow Urban Lake. Water 12(5): 1383.

54. Kumwimba MN, \& Meng F (2019) Roles of ammonia-oxidizing bacteria in improving metabolism and cometabolism of trace organic chemicals in biological wastewater treatment processes: A review. Science of the Total Environment 659: 419-441.

55. Liu ZW, Zhong P, Zhang X, Ning J, Larsen SE, Jeppesen E (2014) Successful restoration of a tropical shallow eutrophic lake: Strong bottom-up but weak top-down effects recorded. Australia-China wetland network research partnership. In Proceedings of the Australia-China Wetland Network Research Partnership Symposium, Nanjing, China, 23-28 March 2014; Kattel G, Ed.; Federation University Australia: Mt. Helen, Australia: 78-86.

56. Lürling M \& van der Grinten E (2003) Life history characteristics of Daphnia exposed to disso Ived microcystin LR and to the cyanobacterium Microcystis aeruginosa with and without microcystins. Environmental Toxicology and Chemistry: An International Journal 22(6): 1281-1287.

57. Lammens EH (1999) The central role of fish in lake restoration and management. Hydrobiologia 395: $191-198$.

58. Lampert W (1981) Toxicity of the blue-green Microcystis aeruginosa: Effective defence mechanism against grazing pressure by Daphni. Internationale Vereinigungfürtheoretische und angewandte Limnologie:

Verhandlungen, 21(3): 1436-1440.

59. Lampert W, Fleckner W, Rai H, \& Taylor BE (1986). Phytoplankton control by grazing zooplankton: A study on the spring clear-water phase 1. Limnology and oceanography, 31(3): 478-490.

60. Lehtiniemi, M. et al. (2005) Turbidity decreases anti-predator behaviour in pike larvae, Esox Lucius. Environmental Biology of Fishes 73: 1-8.

61. Lewtas K, Paterson M, Venema HD, \& Roy D (2015) Manitoba Prairie Lakes: Eutrophication and In-Lake Remediation Treatments. International Institute for Sustainable Development: Winnipeg, Canada.

62. Lindegren M, Möllmann C, \& Hansson LA (2010) Biomanipulation: a tool in marine ecosystem management and restoration? Ecological Applications 20(8): 2237-2248.

63. Loman J (2001) Effects of tadpole grazing on periphytic algae in ponds. Wetlands Ecology and Management 9(2): 135-139.

64. Meerhoff M, Mazzeo N, Moss B, \& Rodríguez-Gallego L (2003) The structuring role of free-floating versus submerged plants in a subtropical shallow lake. Aquatic Ecology 37(4): 377-391. 
65. Maceina MJ, Cichra MF, Betsill RK, \&Bettoli PW (1992) Limnological changes in a large reservoir following vegetation removal by grass carp. Journal of Freshwater Ecology 7(1): 81-95.

66. Mannina G, Pandey A, Larroche C, Ng HY, \& Ngo HH (2020) Current Developments in Biotechnology and Bioengineering: Advanced Membrane Separation Processes for Sustainable Water and Wastewater Management-Case Studies and Sustainability Analysis. Elsevier.

67. McQueen DJ (1990) OPINION Manipulating lake community structure: where do we go from here? Freshwater Biology 23(3): 613-620.

68. Meerhoff M, Clemente JM, de Mello FT, Iglesias C, Pedersen AR, \& Jeppesen E (20 0 7) Can warm climate related structure of littoral predator assemblies weaken the clear water state in shallow lakes? Global Change Biology 13(9): 1888-1897.

69. Mehner T, Benndorf J, Kasprzak P, \&Koschel R (2002) Biomanipulation of lake ecosystems: successful applications and expanding complexity in the underlying science. Freshwater Biology 47(12): 2453-2465.

70. Merel S, Walker D, Chicana R, Snyder S, Baurès E, \& Thomas O (2013) State of knowledge and concerns on cyanobacterial blooms and cyanotoxins. Environment international 59: 303-327.

71. Metcalf JS, \& Codd GA (2012) Cyanotoxins. In 'Ecology of Cyanobacteria II: Their Diversity in Space and Time' (Ed. BA Whitton.) 651-675.

72. Michaels NN (2011) Biomanipulation of the largemouth bass Micropterus salmoides population to control invasive species and eutrophication at the Nature Conservancy's Emiquon Preserve. Western Illinois University.

73. Miura T, \& Wang JI (1985) Chlorophyll a found in feces of phytoplanktivorous cyprinids and its photosynthetic activity: Internationale Vereinigungfürtheoretische und angewandte Limnologie: Verhandlungen 22(4): 26362642.

74. Mustapha MK (2010) Application of biomanipulation in reducing high algal biomass in eutrophicated shallow tropical african reservoirs. Limnetica Internet 4: 1-7.

75. Newman JRE, Anderson NJ, Bennion H, Bowes MJ, Carvalho L, Dawson FH, \& Johnston AM (2006) Eutrophication in rivers: an ecological perspective. Appendix VI of 'Investigating the Effectiveness of NVZ Action programme Measures: Development of a strategy for England' (Lord et al., 2007). Report for DEFRA project WT03017.

76. Nuttle WK (2002) Eco-hydrology's past and future in focus. Eos, Transactions American Geophysical Union 83(19): 205-212.

77. Ofir E, Heymans JJ, Shapiro J, Goren M, Spanier E, \& Gal G (2017) Predicting the impact of Lake Biomanipulation based on food-web modeling-Lake Kinneret as a case study. Ecological Modelling 348: 1424.

78. Ogilvie SC, \& Mitchell SF (1995) A model of mussel filtration in a shallow New Zealand lake, with reference to eutrophication control. Archiv für Hydrobiologie 133(4): 471-482.

79. Pärn O, Lessin G, \&Stips A (2020) Effects of sea ice and wind speed on Phytoplankton spring bloom in Central and Southern Baltic Sea. bioRxiv.

80. Paul B, Bhattacharya SS, \& Gogoi N (2020) Primacy of ecological engineering tools for combating eutrophication: An ecohydrological assessment pathway. Science of The Total Environment: 143171.

81. Pflugmacher S, Wiegand C, Oberemm A, Beattie KA, Krause E, Codd GA, \& Steinberg CE (1998) Identification of an enzymatically formed glutathione conjugate of the cyanobacterial hepatotoxin microcystin-LR: the first step of detoxication. Biochimica et Biophysica Acta (BBA)-General Subjects 1425(3): 527-533. 
82. Ping XIE (1996) Experimental studies on the role of planktivorous fishes in the elimination of Microcystis bloom from Donghu Lake using enclosure method. Chinese Journal of Oceanology and Limnology 14(3): 193-204.

83. Pogozhev PI \& Gerasimova TN (2001) The Effect of Zooplankton on Microalgae Blooming and Water Eutrophication. Water Resources 420-427.

84. Porter KG (1980) Nutritional adequency, manageability, and toxicity as factors that determine the food quality of green and blue algae for Daphnia. In Am. Soc. Limnol. Oceanogr. Spec. Symp 3:268-281

85. Richter AF (1986) Biomanipulation and its feasibility for water quality management in shallow eutrophic water bodies in the Netherlands. Hydrobiological Bulletin 20(1-2): 165-172.

86. Sánchez KF, Huntley N, Duffy MA, \& Hunter MD (2019) Toxins or medicines? Phytoplankton diets mediate host and parasite fitness in a freshwater system. Proceedings of the Royal Society B, 286(1894): 20182231.

87. Sanni S, \&Wærvågen SB (1990) Oligotrophicationas a result of planktivorous fish removal with rotenone in the small, eutrophic, Lake Mosvatn, Norway. Hydrobiologia 200(1): 263-274.

88. Sarnelle O, \& Wilson AE (2005) Local adaptation of Daphnia pulicaria to toxic cyanobacteria. Limnology and oceanography 50(5): 1565-1570

89. Schindler DW (1974) Eutrophication and recovery in experimental lakes: implications for lake management. Science 184(4139): 897-899.

90. Schoenberg SA \& Carlson RE 1984 Direct and indirect effects of zooplankton grazing on phytoplankton in a hypereutrophic lake. - Oikos 42: 291-302.

91. Sebastiá-Frasquet MT, Aguilar-Maldonado JA, Herrero-Durá I, Santamaría-del-Ángel E, Morell-Monzó S, \&Estornell J (2020). Advances in the Monitoring of Algal Blooms by Remote Sensing: A Bibliometric Analysis. Applied Sciences 10(21): 7877.

92. Shapiro J (1990) Biomanipulation: the next phase-making it stable. Hydrobiologia 200(1): $13-27$.

93. Shapiro J, Lamarra V \& Lynch M (1975) Biomanipulation: an ecosystem approach to lake restoration. In: Brezonik PL \& Fox JL (eds), Proc. Symp. on Water Quality Management Through Biological Control. University of Florida: 85-96.

94. Sharma CM (2015) Can bio-manipulation be related to fisheries and aquaculture through environmental pollution perspective?. Fisheries and Aquaculture Journal.

95. Sharma CM, Borgstrøm R, \&Rosseland BO (2010) Biomanipulation in Lake Årungen, Norway: A tool for biological control. In Eutrophication: causes, consequences and control: 295-323. Springer, Dordrecht.

96. Sharpley AN, Kleinman PJ, Heathwaite AL, Gburek WJ, Folmar GJ, \& Schmidt JP (2008) Phosphorus loss from an agricultural watershed as a function of storm size. Journal of Environmental Quality 37(2): 362-368.

97. Skov C, Hansen JH, Baktoft H, Brodersen J, Brönmark C, Hansson LA, ... \& Nilsson PA (2019) Biomanipulating streams: a supplementary tool in lake restoration. Hydrobiologia 829(1): 205-216.

98. Smith VH, \& Schindler DW (2009) Eutrophication science: where do we go from here? Trends in ecology \& evolution 24(4): 201-207.

99. Søndergaard M, Bjerring R, \& Jeppesen E (2013) Persistent internal phosphorus loading during summer in shallow eutrophic lakes. Hydrobiologia 710(1): 95-107.

100. Søndergaard M, Jeppesen E, Lauridsen TL, Skov C, Van Nes EH, Roijackers R, \& Portielje ROB (2007) Lake restoration: successes, failures and long-term effects. Journal of Applied ecology 44(6): 1095-1105.

101. Søndergaard M, Jeppesen E, Mortensen E, Dall E, Kristensen P, \& Sortkjær O (1990) Phytoplankton biomass reduction after planktivorous fish reduction in a shallow, eutrophic lake: a combined effect of reduced internal 
P-loading and increased zooplankton grazing. Hydrobiologia 200(1): 229-240.

102. Teixeira-De Mello, Franco, Meerhoff M, Pekcan H, Zeyne P, \& Jeppesen E (2009) Substantial differences in littoral fish community structure and dynamics in subtropical and temperate shallow lakes. Freshwater Biology 54(6):1202-1215.

103. Tillmanns AR, Wilson AE, Pick FR, \&Sarnelle O (2008) Meta-analysis of cyanobacterial effects on zooplankton population growth rate: species-specific responses. Fundamental and Applied Limnology/Archivfür Hydrobiologie, 171(4):285-295.

104. Timms RM, \& Moss B (1984) Prevention of growth of potentially dense phytoplankton populations by zooplankton grazing, in the presence of zooplanktivorousfish, in a shallow wetland ecosystem. Limnology and Oceanography 29(3):472-486.

105. UNESCO (2016). Ecohydrology as an integrative science from molecular to basin scale: historical evolution, advancements and implementation activities. 1-28 https://unesdoc.unesco.org/ark:/48223/pf0000245512 retrieved on 31/01/02021.

106. Van De Bund WJ, \& Van Donk E (2020) Short term and long term effects of zooplanktivorous fish removal in a shallow lake: a synthesis of 15 years of data from Lake Zwemlust. Freshwater Biology 47(12): 2380-2387.

107. Waajen GW, Van Bruggen NC, Pires LMD, Lengkeek W, \&Lürling M (2016) Biomanipulation with quagga mussels (Dreissenarostriformisbugensis) to control harmful algal blooms in eutrophic urban ponds. Ecological engineering 90: 141-150.

108. Wang L, Sun J, Zheng W, Huang T, Zhang Y, Wu Z, \& He F (2018) Effects of a Combined Biological Restoration Technology on Nitrogen and Phosphorus Removal from Eutrophic Water. Polish Journal of Environmental Studies: 27(5).

109. Webber CM (2014) Combating Eutrophication: An Ecosystem Scale Analysis of Aluminum Sulfate (Alum) Effectiveness among lakes, with comparison to Alum and Biomanipulation Dual Treatment.

110. Wetzel RG (2001) Planktonic communities: zooplankton and their interactions with fish. Limnology: Lake and River Ecosystems: 395-488.

111. Wickramasinghe NK, \& Yatigammana SK (2017) Detection of suitable zooplankton from three taxonomic groups for application in biomanipulation. Ceylon Journal of Science: 46(1).

112. Wiegand C, \&Pflugmacher S (2005) Ecotoxicological effects of selected cyanobacterial secondary metabolites a short review. Toxicology and applied pharmacology 203(3): 201-218.

113. Will JS, \& Wright DI (1984) Lake restoration by biomanipulation: Round Lake, Minnesota, the first two years. Freshwater biology 14(4): 371-383.

114. Wilson AE, Sarnelle O, \& Tillmanns AR (2006) Effects of cyanobacterial toxicity and morphology on the population growth of freshwater zooplankton: Meta analyses of laboratory experiments. Limnology and Oceanography 51(4): 1915-1924.

115. Wolanski E, \& Elliott M (2015) Estuary restoration. Elsevier. ISBN: 9780444633989

116. Wright DI, \& Shapiro J (1984) Nutrient reduction by biomanipulation: An unexpected phenomenon and its possible cause: With 4 figures and 1 table in the text. Internationale Vereinigung für theoretische und angewandte Limnologie: Verhandlungen 22(1): 518-524.

117. Wu N, Dong X, Liu Y, Wang C, Baattrup-Pedersen A, \& Riis T (2017) Using river microalgae as indicators for freshwater biomonitoring: Review of published research and future directions. Ecological Indicators 81: 124131. 
118. Xie P, \& Liu J (2001) Practical success of biomanipulation using filter-feeding fish to control cyanobacteria blooms: a synthesis of decades of research and application in a subtropical hypereutrophic lake. TheScientificWorldJournal 1: 337-356.

119. Yi C, Guo L, Ni L, \& Luo C (2016) Silver carp exhibited an enhanced ability of biomanipulation to control cyanobacteria bloom compared to bighead carp in hypereutrophic Lake Taihu mesocosms. Ecological Engineering 89: 7-13.

120. Zalewski M, Janauer GA, \& Jolankai G (1997) Ecohydrology. A New Paradigm for the Sustainable Use of Aquatic Resources. International Hydrological Programme IHP-V Technical Documents in Hydrology (7).

121. Zapletal T, Mareš J, Jurajda P, \& Všetičková L (2013) The food of common bream (Abramis brama L.) in a biomanipulated water supply reservoir. Acta Universitatis Agriculturae et Silviculturae Mendelianae Brunensis, 60(6), 357-366.

122. Zhang S, Wang Y, He W, Wu M, Xing M, Yang J, ... \& Pan M (2014) Impacts of temperature and nitrifying community on nitrification kinetics in a moving-bed biofilm reactor treating polluted raw water. Chemical Engineering Journal 236: 242-250.

123. Zhang X, Tang Y, Jeppesen E, \& Liu Z (2017) Biomanipulation-induced reduction of sediment phosphorus release in a tropical shallow lake. Hydrobiologia 794(1): 49-57.

124. Zhang Y, Luo P, Zhao S, Kang S, Wang P, Zhou M, \&Lyu J (2020) Control and remediation methods for eutrophic lakes in the past 30 years. Water Science and Technology 81(6): 1099-1113.

125. Zhao S, Fang J, Peng C, Tang Z, \& Piao S (2006) Patterns of fish species richness in China's lakes. Global Ecology and Biogeography 15(4): 386-394.

\section{Tables}

Table 1. Innovative biomanipulation vis-à-vis eco-bioengineering for sustainable and long-term restoration of eutrophic water bodies 


\begin{tabular}{|c|c|c|c|c|c|}
\hline Description & Key Species & Key drivers & Target feature & Location & References \\
\hline $\begin{array}{l}\text { Biomanipulation } \\
\text { of microbial } \\
\text { pathogens, } \\
\text { aquatic } \\
\text { macrophytes } \\
\text { and fishes } \\
\text { combined with } \\
\text { Barley straw } \\
\text { treatment to } \\
\text { eutrophic waters }\end{array}$ & $\begin{array}{l}\text { Fishes } \\
\text { (Tilapia, } \\
\text { Heterotis, } \\
\text { Synodontis } \\
\text { etc.), } \\
\text { zooplankton } \\
\text { (Daphnia and } \\
\text { Bosmina), } \\
\text { virus, bacteria, } \\
\text { fungi and } \\
\text { protozoa, } \\
\text { macrophytes } \\
\text { and barley } \\
\text { straw }\end{array}$ & Algal biomass & Phytoplankton & $\begin{array}{l}\text { African } \\
\text { reservoirs, } \\
\text { South Africa }\end{array}$ & Mustapha 2010 \\
\hline $\begin{array}{l}\text { Biomanipulation } \\
\text { in polluted lake } \\
\text { using northern } \\
\text { pike }\end{array}$ & $\begin{array}{l}\text { Northern } \\
\text { Pike (Esox } \\
\text { lucius) }\end{array}$ & $\begin{array}{l}\text { DDT, PCB, HCB } \\
\text { and } \mathrm{HCE}\end{array}$ & $\begin{array}{l}\text { Zooplankton, } \\
\text { macroinvertebrates, } \\
\text { and fish }\end{array}$ & $\begin{array}{l}\text { Lake } \\
\text { årungen, } \\
\text { Norway, } \\
\text { Europe }\end{array}$ & $\begin{array}{l}\text { Sharma et al } \\
2010\end{array}$ \\
\hline $\begin{array}{l}\text { Biomanipulation } \\
\text { of planktivorous } \\
\text { fishes to restore } \\
\text { eutrophic waters }\end{array}$ & $\begin{array}{l}\text { Planktivorous } \\
\text { fishes (cod } \\
\text { and sprat) }\end{array}$ & $\begin{array}{l}\text { Sprat } \\
\text { spawning } \\
\text { stock biomass } \\
\text { (SSB) }\end{array}$ & Phytoplankton & $\begin{array}{l}\text { Narrow } \\
\text { straits and } \\
\text { shallow sills } \\
\text { in Baltic } \\
\text { Sea, } \\
\text { Denmark, } \\
\text { Europe }\end{array}$ & $\begin{array}{l}\text { Lindegren et al } \\
2010\end{array}$ \\
\hline $\begin{array}{l}\text { Biomanipulation } \\
\text { by changing the } \\
\text { feeding habits } \\
\text { of fishes in } \\
\text { reservoirs }\end{array}$ & $\begin{array}{l}\text { Fish (Abramis } \\
\text { brama) }\end{array}$ & Zooplankton & $\begin{array}{l}\text { Macrophytes, } \\
\text { benthic } \\
\text { macroinvertebrates } \\
\text { and zooplankton }\end{array}$ & $\begin{array}{l}\text { Hamry } \\
\text { reservoir in } \\
\text { River } \\
\text { Chrudimka, } \\
\text { Czech } \\
\text { Republic, } \\
\text { Europe }\end{array}$ & $\begin{array}{l}\text { Zapletal et al } \\
2012\end{array}$ \\
\hline $\begin{array}{l}\text { Biomanipulation } \\
\text { of fishes to } \\
\text { reduce } \\
\text { phosphorus } \\
\text { loadings from } \\
\text { groundwater to } \\
\text { a eutrophic } \\
\text { seepage lake }\end{array}$ & $\begin{array}{l}\text { Cyprinid } \\
\text { fishes }\end{array}$ & TP & $\begin{array}{l}\text { Total phosphorus } \\
\text { loadings }\end{array}$ & $\begin{array}{l}\text { Lake Væng, } \\
\text { Denmark, } \\
\text { Europe }\end{array}$ & $\begin{array}{l}\text { Kidmose et al } \\
2013\end{array}$ \\
\hline $\begin{array}{l}\text { Biomanipulation } \\
\text { of fishes to } \\
\text { reduce P release } \\
\text { form sediment } \\
\text { in eutrophic } \\
\text { lakes }\end{array}$ & Fishes & $\begin{array}{l}\text { TP, chlorophyll- } \\
\text { a }\end{array}$ & $\begin{array}{l}\text { Total phosphorus } \\
\text { from sediments }\end{array}$ & $\begin{array}{l}\text { Lakes in } \\
\text { Denmark, } \\
\text { Europe }\end{array}$ & $\begin{array}{l}\text { Søndergaard et } \\
\text { al. } 2013\end{array}$ \\
\hline $\begin{array}{l}\text { Biomanipulation } \\
\text { in temperate } \\
\text { eutrophic lakes } \\
\text { involving } \\
\text { planktivorous } \\
\text { and } \\
\text { benthivorous } \\
\text { fish, a review }\end{array}$ & $\begin{array}{l}\text { Planktivorous } \\
\text { and } \\
\text { benthivorous } \\
\text { fish }\end{array}$ & $\begin{array}{l}\text { Nutrients, lake } \\
\text { salinity and } \\
\text { conductivity } \\
\text { water colour, } \\
\text { DOC etc. }\end{array}$ & $\begin{array}{l}\text { Zooplankton, } \\
\text { phytoplankton }\end{array}$ & $\begin{array}{l}\text { Temperate } \\
\text { eutrophic } \\
\text { lakes, } \\
\text { Generic }\end{array}$ & $\begin{array}{l}\text { Bernes et ql } \\
2013\end{array}$ \\
\hline Description & Key Species & Key drivers & Target feature & Location & References \\
\hline
\end{tabular}




\begin{tabular}{|c|c|c|c|c|c|}
\hline $\begin{array}{l}\text { Treatment of } \\
\text { eutrophic lakes } \\
\text { by alum and } \\
\text { Biomanipulation } \\
\text { Dual } \\
\text { Treatment }\end{array}$ & Cyanobacteria & $\begin{array}{l}\text { TP, TN, } \\
\text { chlorophyll-a, } \\
\text { pH, } \\
\text { microcystin }\end{array}$ & HABs & $\begin{array}{l}\text { Fremont } \\
\text { Lakes State } \\
\text { Recreation } \\
\text { Area, } \\
\text { Nebraska, } \\
\text { USA North } \\
\text { America }\end{array}$ & Webber 2014 \\
\hline $\begin{array}{l}\text { Biomanipulation } \\
\text { of snail to } \\
\text { reduce algal } \\
\text { blooms in } \\
\text { eutrophic ponds }\end{array}$ & $\begin{array}{l}\text { Snail } \\
\text { (Lymnaea sp.) }\end{array}$ & Phytoplankton & $\begin{array}{l}\text { HABs (Microcystis } \\
\text { aeruginosa) }\end{array}$ & $\begin{array}{l}\text { Ponds in } \\
\text { Jiangsu } \\
\text { Province, } \\
\text { China, East } \\
\text { Asia }\end{array}$ & Jin et al 2014 \\
\hline $\begin{array}{l}\text { Biomanipulation } \\
\text { of fishes by } \\
\text { capturing fishes } \\
\text { with traditional } \\
\text { anglers in } \\
\text { reservoirs }\end{array}$ & $\begin{array}{l}\text { Fishes } \\
\text { (common } \\
\text { carp, } \\
\text { Goldfish and } \\
\text { bleak) }\end{array}$ & TP, TN & $\begin{array}{l}\text { Total phosphorus } \\
\text { and Total Nitrogen } \\
\text { loadings }\end{array}$ & $\begin{array}{l}\text { Reservoirs } \\
\text { in Southern } \\
\text { Portugal, } \\
\text { Europe }\end{array}$ & $\begin{array}{l}\text { Amaral et al } \\
2015\end{array}$ \\
\hline $\begin{array}{l}\text { Biomanipulation } \\
\text { of fishes to } \\
\text { reduce total } \\
\text { phosphorus in } \\
\text { eutrophic waters }\end{array}$ & $\begin{array}{l}\text { Fishes } \\
\text { (catfish and } \\
\text { carp) }\end{array}$ & $\mathrm{TP}$ & TP loadings & $\begin{array}{l}7 \text { South } \\
\text { African } \\
\text { reservoirs, in } \\
\text { Gauteng, } \\
\text { North West } \\
\text { and } \\
\text { Limpopo } \\
\text { provinces, } \\
\text { South Africa }\end{array}$ & $\begin{array}{l}\text { Hart and } \\
\text { Harding } 2015\end{array}$ \\
\hline $\begin{array}{l}\text { Biomanipulation } \\
\text { involving fish to } \\
\text { reduce } \\
\text { persistent } \\
\text { organic } \\
\text { pollutants }\end{array}$ & $\begin{array}{l}\text { Fish (Northern } \\
\text { pike, Esox } \\
\text { lucius L.) }\end{array}$ & $\begin{array}{l}\text { Mercury and } \\
\text { persistent } \\
\text { organochlorine }\end{array}$ & Fish & $\begin{array}{l}\text { Lake } \\
\text { Arungen, } \\
\text { Norway } \\
\text { Europe }\end{array}$ & Sharma 2015 \\
\hline $\begin{array}{l}\text { Manipulation of } \\
\text { diets in mussels } \\
\text { in relation to } \\
\text { removal of algal } \\
\text { toxins }\end{array}$ & $\begin{array}{l}\text { Mussels } \\
\text { (Anodonta } \\
\text { woodiana) }\end{array}$ & Chlorophyll a & $\begin{array}{l}\text { Algal toxins } \\
\text { (Microcystis } \\
\text { aeruginosa and } \\
\text { Scenedesmus } \\
\text { obliquus) }\end{array}$ & $\begin{array}{l}\text { Lake Taihu, } \\
\text { China, East } \\
\text { Asia }\end{array}$ & Liu 2014 \\
\hline $\begin{array}{l}\text { Biomanipulation } \\
\text { in eutrophic } \\
\text { urban ponds } \\
\text { using Quagga } \\
\text { mussels, } \\
\text { zooplankton } \\
\text { and } \\
\text { phytoplankton }\end{array}$ & $\begin{array}{l}\text { Quagga } \\
\text { mussels } \\
\text { (Dreissena } \\
\text { rostriformis } \\
\text { bugensis) }\end{array}$ & $\begin{array}{l}\text { TN, TP, } \\
\text { chlorophyll-a, } \\
\text { suspended } \\
\text { solids, pH etc. }\end{array}$ & $\begin{array}{l}\text { Zooplankton } \\
\text { (Leptodora kindtii, } \\
\text { Naupliisp. etc.) } \\
\text { and HABs } \\
\text { (Scenedesmus } \\
\text { obliquus } \\
\text { Microcystis } \\
\text { aeruginosa) }\end{array}$ & $\begin{array}{l}\text { Urban } \\
\text { ponds in } \\
\text { The } \\
\text { Netherlands, } \\
\text { Europe }\end{array}$ & $\begin{array}{l}\text { Waajen et al } \\
2016\end{array}$ \\
\hline Description & Key Species & Key drivers & Target feature & Location & References \\
\hline $\begin{array}{l}\text { Biomanipulation } \\
\text { of tropical } \\
\text { eutrophic lakes } \\
\text { by removal of } \\
\text { fishes and } \\
\text { transplantation } \\
\text { of macrophyte }\end{array}$ & $\begin{array}{l}\text { Fishes and } \\
\text { macrophytes }\end{array}$ & $\begin{array}{l}\text { TP, chlorophyll- } \\
\text { a }\end{array}$ & Nutrient dynamics & $\begin{array}{l}\text { Huizhou } \\
\text { West Lake, } \\
\text { China, East } \\
\text { Asia }\end{array}$ & $\begin{array}{l}\text { Jensen et al } \\
2016\end{array}$ \\
\hline $\begin{array}{l}\text { In-vitro } \\
\text { biomanipulation }\end{array}$ & $\begin{array}{l}\text { Zooplankton } \\
\text { (Cladocera, }\end{array}$ & Algal cells & $\begin{array}{l}\text { Phytoplankton } \\
\text { (Chlorella sp., }\end{array}$ & $\begin{array}{l}20 \\
\text { reservoirs, }\end{array}$ & $\begin{array}{l}\text { Wickramasinghe } \\
\text { and }\end{array}$ \\
\hline
\end{tabular}




\begin{tabular}{|c|c|c|c|c|c|}
\hline $\begin{array}{l}\text { of zooplankton } \\
\text { and } \\
\text { phytoplankton } \\
\text { for potential } \\
\text { treatment of } \\
\text { eutrophication }\end{array}$ & $\begin{array}{l}\text { Copepoda } \\
\text { and } \\
\text { Ostracoda) }\end{array}$ & & $\begin{array}{l}\text { Crucigenia sp., } \\
\text { Scenedesmus sp., } \\
\text { Monoraphidium } \\
\text { sp.) }\end{array}$ & Sri Lanka & $\begin{array}{l}\text { Yatigammana } \\
2017 f\end{array}$ \\
\hline $\begin{array}{l}\text { Biomanipulation } \\
\text { using fishes and } \\
\text { phytoplankton } \\
\text { using a food } \\
\text { web model to } \\
\text { construct a } 10 \\
\text { year } \\
\text { biomanipulation } \\
\text { management } \\
\text { scenario }\end{array}$ & $\begin{array}{l}\text { St. Peter's fish, } \\
\text { mugilids, } \\
\text { mugil and } \\
\text { silver carp }\end{array}$ & $\begin{array}{l}\text { Phytoplankton } \\
\text { and } \\
\text { zooplankton }\end{array}$ & $\begin{array}{l}\text { Zooplankton, } \\
\text { phytoplankton } \\
\text { (Aphanizomen, } \\
\text { Aulacosira, } \\
\text { Microcystis, } \\
\text { Peridinium, } \\
\text { Debarya) } \\
\text { and nanoplankton }\end{array}$ & $\begin{array}{l}\text { Lake } \\
\text { Kinneret, } \\
\text { Middle East }\end{array}$ & Ofir et al 2017 \\
\hline $\begin{array}{l}\text { Biomanipulation } \\
\text { of cyprinid } \\
\text { fishes to restore } \\
\text { eutrophic lake }\end{array}$ & $\begin{array}{l}\text { Cyprinid } \\
\text { fishes }\end{array}$ & $\begin{array}{l}\text { Habitating of } \\
\text { cyprinid fishes }\end{array}$ & Clarity of water & $\begin{array}{l}\text { Lake Søga } \\
\text { rd and a } \\
\text { Danish lake, } \\
\text { Denmark }\end{array}$ & Skov et al 2019 \\
\hline $\begin{array}{l}\text { Biomanipulation } \\
\text { of fishes } \\
\text { combined with } \\
\text { physical } \\
\text { treatment in } \\
\text { eutrophic lake }\end{array}$ & $\begin{array}{l}\text { Fishes (pike } \\
\text { and pikeperch } \\
\text { fry) }\end{array}$ & $\begin{array}{l}\text { TP, chlorophyll- } \\
\text { a }\end{array}$ & Cyanobacteria & $\begin{array}{l}\text { Swarze } \\
\text { \dzkie Lake, } \\
\text { Poland }\end{array}$ & $\begin{array}{l}\text { Kowalczewska- } \\
\text { Madura et al } \\
2020\end{array}$ \\
\hline
\end{tabular}

\section{Figures}




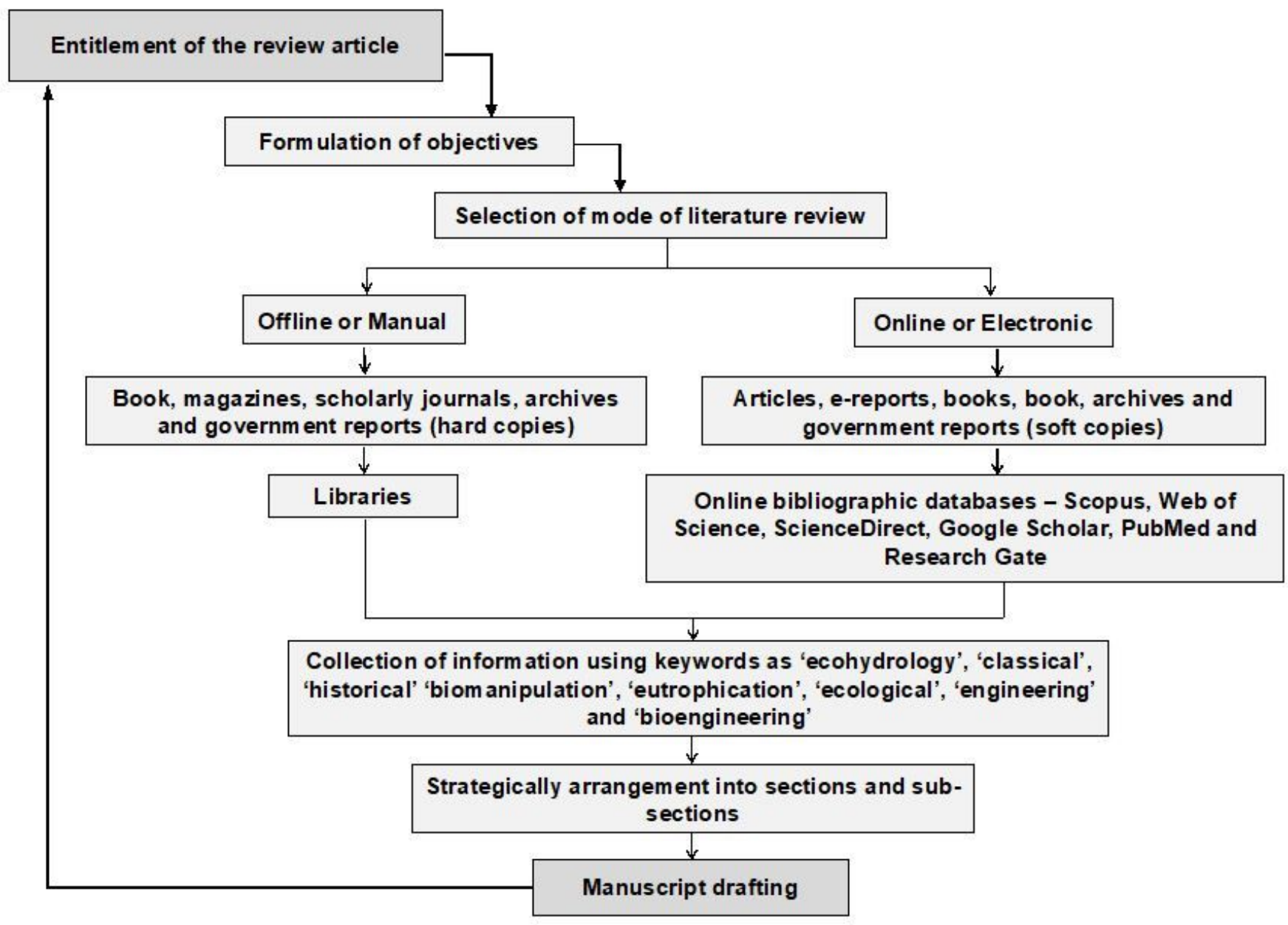

Figure 1

Flowchart of methodological approach showing pathways of retrieving information and drafting of review article (adapted from Paul et al. 2020) 


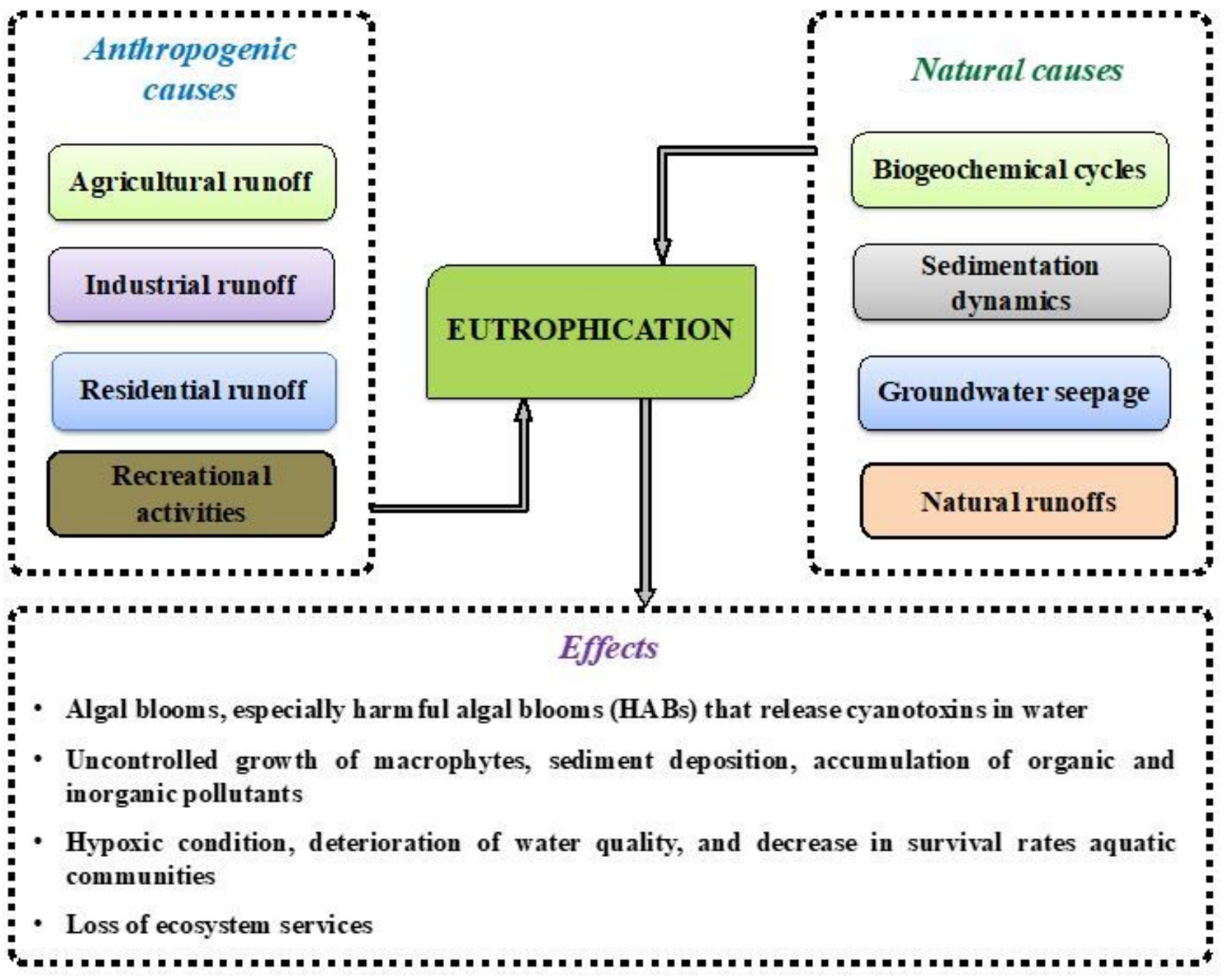

Figure 2

Schematic diagram describing the root causes and effects of eutrophication 


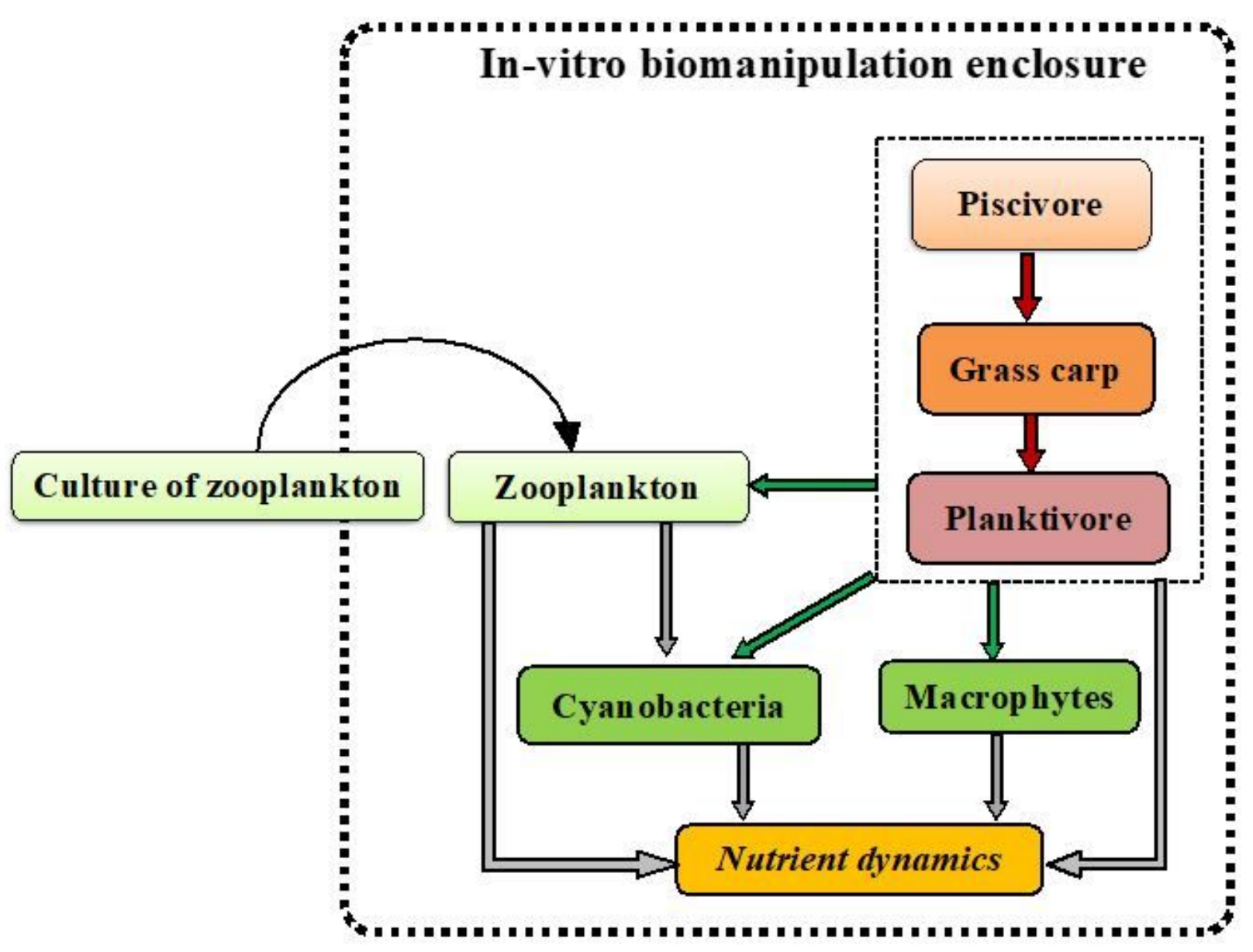

Figure 3

Schematic representation of the food web in an in-vitro biomanipulation experiment mimicking natural aquatic ecosystem 


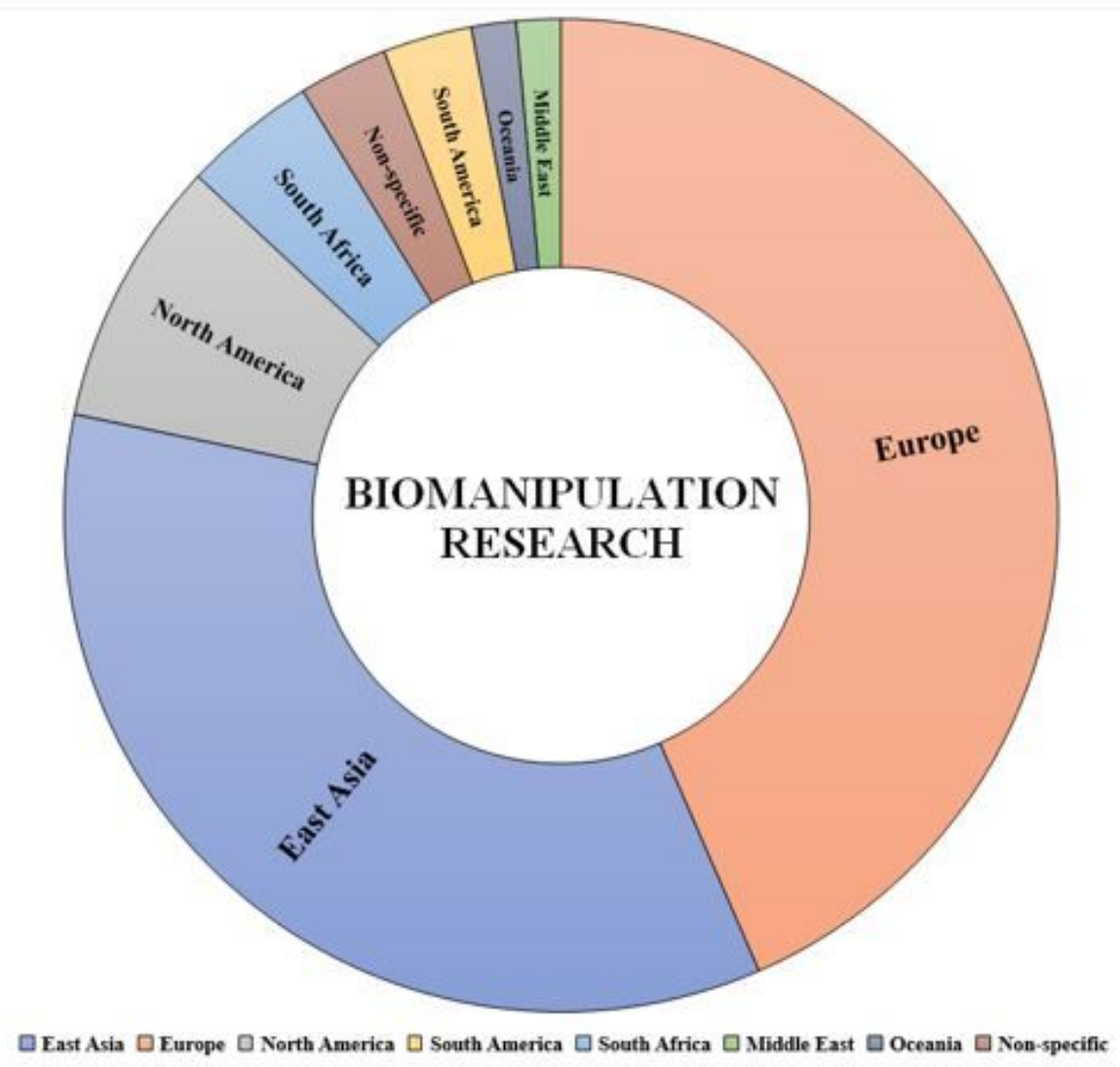

Figure 4

Current worldwide scenario of biomanipulation research

\section{Supplementary Files}

This is a list of supplementary files associated with this preprint. Click to download.

- SupplementaryFileNayanmoniGogoi.xlsx 